Review

\title{
You Are What You Eat-The Relationship between Diet, Microbiota, and Metabolic Disorders-A Review
}

\author{
Małgorzata Moszak * (1), Monika Szulińska and Paweł Bogdański \\ Department of Treatment of Obesity, Metabolic Disorders and Clinical Dietetics, Poznan University of Medical \\ Sciences, 61-569 Poznań, Poland; mszulinska1@wp.pl (M.S.); pbogdanski@ump.edu.pl (P.B.) \\ * Correspondence: mmoszak@ump.edu.pl; Tel.: +48-6185-49-377
}

Received: 20 March 2020; Accepted: 14 April 2020; Published: 15 April 2020

check for updates

\begin{abstract}
The gut microbiota (GM) is defined as the community of microorganisms (bacteria, archaea, fungi, viruses) colonizing the gastrointestinal tract. GM regulates various metabolic pathways in the host, including those involved in energy homeostasis, glucose and lipid metabolism, and bile acid metabolism. The relationship between alterations in intestinal microbiota and diseases associated with civilization is well documented. GM dysbiosis is involved in the pathogenesis of diverse diseases, such as metabolic syndrome, cardiovascular diseases, celiac disease, inflammatory bowel disease, and neurological disorders. Multiple factors modulate the composition of the microbiota and how it physically functions, but one of the major factors triggering GM establishment is diet. In this paper, we reviewed the current knowledge about the relationship between nutrition, gut microbiota, and host metabolic status. We described how macronutrients (proteins, carbohydrates, fat) and different dietary patterns (e.g., Western-style diet, vegetarian diet, Mediterranean diet) interact with the composition and activity of GM, and how gut bacterial dysbiosis has an influence on metabolic disorders, such as obesity, type 2 diabetes, and hyperlipidemia.
\end{abstract}

Keywords: gut microbiota; diet; metabolic disorders; obesity; dyslipidemia; diabetes; short-chain fatty acid; vegetarian; Western-style diet

\section{Introduction}

In recent years, there has been a growing interest in the role of gut microbiota (GM) and their implications for human health, especially in the context of metabolic disorders (obesity, type 2 diabetes, dyslipidemia), which increase the risk of cardiovascular incidents and thus the number of deaths in developed countries. One of the most important factors affecting the state of the microbiota is undoubtedly diet. This manuscript discusses the impact of different types of diets on the microbiota and the relationship between diet, the state of the intestinal bacterial flora, and the development of selected metabolic disorders.

The gut microbiota is defined as the community of microorganisms (bacteria, archaea, fungi, viruses) colonizing the gastrointestinal tract $[1,2]$. The number and type of microorganisms differ along the gastrointestinal tract, with their distribution being determined by $\mathrm{pH}$, oxygen and nutrient availability, digestive flow rates, and secreted enzymes. For example, the concentration of bacteria in the stomach is relatively small (10 CFU/g), increasing steadily to $10^{7} \mathrm{CFU} / \mathrm{g}$ in the ileum and $10^{12} \mathrm{CFU} / \mathrm{g}$ in the colon [3]. The upper section of the digestive tract is colonized mainly by aerobic bacteria, while the lower section is mainly populated by anaerobic bacteria. The main clusters residing in the human digestive tract are from five phyla-Firmicutes (79.4\%; Ruminococcus, Clostridium, Eubacteria) and Bacterioidetes (16.9\%; Porphyromonas, Prevotella), followed by phyla Proteobacteria (1\%), Actinobacteria 
(2.5\%; Bifidobacterium), and Verrumicrobia $(0.1 \%)$ [4,5]. In the proximal gut, the dominant groups are Lactobacillus (Firmicutes), Veillonella (Firmicutes), and Helicobacter (Proteobacteria). In the duodenum, jejunum, and ileum, the most numerous groups are Bacilli (Firmicutes), Streptococcaceae (Firmicutes), and Actinomycinaeae, and in the colon, an increased proportion of Lachnospiraceae (Firmicutes) and Bacteroidetes are observed [6]. GM regulates various metabolic pathways in the host, including those involved in energy homeostasis, glucose metabolism, and lipid metabolism [6]. Because of its broad metabolic activity, GM is often called "a new virtual metabolic organ" [7]. Previous studies have shown that GM plays important roles in nutrient degradation and adsorption [3], short-chain fatty acids (SCFAs), amines, phenols/indoles, and sulfurous compounds production [8], vitamin B and $\mathrm{K}$ synthesis [9], the bioavailability of minerals, and the metabolism of bile acids [10]. GM helps maintain gut integrity by stabilizing cell-cell junctions, and it acts in restoring the epithelial barrier after damage [11]. Maintaining a proper microbiota composition plays a critical role in protection against pathogens and is an integral part of the overall host immune response [6]. By regulating the release of neurotransmitters and other neuroactive substances (serotonin, dopamine, $\gamma$-aminobutyric acid (GABA)), GM influences the central nervous system [12].

Multiple factors modulate the composition of the microbiota and its activity. In humans, the gut flora evolves in several stages, but the most dynamic period in GM establishment is the first one to two years of life. The microbial pattern shaping in the first 2-5 years of life will then determine the GM profile in later stages of development-in early childhood when GM grows and diversifies, and in adolescence when the community of bacteria in the gastrointestinal tract stabilizes [13]. GM profiles vary between different races/ethnicity and sex/gender [14]. The individual microbiota pattern is influenced by antibiotic use (especially in the first years after birth) $[15,16]$, medication (nonsteroidal anti-inflammatory drugs, proton pump inhibitors), infections, and chronic stress. The size, species composition, and diversity of bacteria in the human digestive tract are also shaped by host genotype, physical activity level, personal hygiene, and xenobiotics [17]. But one of the most significant roles is played by nutrition: composition of the diet, dietary pattern, and long-term dietary habits (consumption of snacks and junk food, late-night eating, breakfast skipping, nutritional habits) [18,19].

In this paper, we reviewed the current knowledge about the relationship between nutrition, gut microbiota, and host metabolic status. We described how diet interacts with the composition and physiological activity of GM and how gut dysbiosis influences metabolic disorders, such as obesity, type 2 diabetes, and hyperlipidemia.

\section{Diet and Gut Microbiota}

Diet affects multiple aspects of human health. It is well documented that improper nutrition patterns, e.g., a Western-style diet (WSD) or a high-fat diet (HFD), are linked to chronic diseases of civilization, such as obesity, type 2 diabetes, and cardiovascular disease (CVD) [19]. Long-term nutritional habits are essential not only for determining the human health status but also for maintaining high diversity and abundance of microbial populations in the GI tract, termed "eubiosis" [20].

\subsection{Infant's Diet and Gut Microbiota Establishment}

The first 2-5 years of life play a significant role in determining the GM. An infant's microbiome will closely resemble their mother's microbiome, which results from influences by many of the maternal microbiomes-mouth, skin, vagina, gastrointestinal (GI) tract, and breastmilk [21]. One of the most crucial factors contributing to GM in childhood is diet. Several studies have discovered that distinct infant microbiome profiles correlate with different nutritional aspects, such as breastfeeding, formula-feeding (formula ingredients) [22], maternal gestational diet [22], time of introduction of solid foods, or model of diet weaning [23,24].

World Health Organization recommends breastfeeding as the best method for infant nutrition for the first six months of life and then continued supplemental breastfeeding up to 2 years and beyond [22]. Breastfeeding plays an essential role in infant metabolic and immunological programming and positively 
influences the microbiota diversity and composition. The variety of the gut microbial community in the first month of life is rather small, but most studies indicate differences in the microbiota of formula-fed versus breast-fed infants. Newborns fed with mother's breast milk have a higher abundance of beneficial bacteria species compared to formula-fed children. Breastfeeding is associated with favorable alteration of infant GM (high colonization with Bifidobacterium and Lactobacillus, Staphylococcus and Bacteroides, low colonization with Clostridium, Escherichia), in addition to inhibiting colonization by potential pathogens (Escherichia coli, Helicobacter jejuni, Shigella, Vibrio cholera, Salmonella), as described in several previous studies [25-27]. In comparison, formula-fed infants are enriched in functions typical of the adult microbiota and have higher counts of Clostridia (C. paraputrificum, C. perfringens, C. clostridiiforme, C. difficile, and C. tertium), Streptococcus (S. bovis, S. faecalis, and S. faecium), and Proteobacteria (Enterobacter cloacae, Citrobacter spp., and Bilophila wadsworthia) than do breast-fed infants, and with delayed colonization by Bifidobacteria [22]. The beneficial effect of mother's breast milk on the microbiota formation results from the content of bioactive compounds, mainly human milk oligosaccharide (HMO), HMO-related metabolites, immunological components (secretory IgA), and fatty acids [26]. Because of the "bifidogenic effect", HMO provides optimal growth factors for promoting and supporting specific microbial establishment. The higher presence of Bifidobacterium spp. in early life entails protection against obesity [28]. Fatty acids and monoglycerides arising from the hydrolysis of milk triglycerides support the infant's innate immunity against several pathogens, including Giardia lamblia, Haemophilus influenzae, Group B streptococci, Staphylococcus epidermidis, respiratory syncytial virus, and herpes simplex virus type 1 [29]. The positive role of breastfeeding is likely to be caused by the influence of age-appropriate and environment-adjusted gut colonization and provides numerous health benefits, such as protection against obesity, diabetes, and other components of metabolic syndrome in adulthood [30,31]. However, it should be remembered that the composition of both macronutrients and microbiota of breast milk depends on many factors, such as mother's health [30], gestational weight gain, mode of delivery [31], duration of breastfeeding, and model of breastfeeding (exclusively breastfeeding vs. non-exclusively breastfeeding), and these are what ultimately affect the infant's GM pattern [26].

Following breastfeeding or formula-feeding, weaning and the introduction of solid foods are associated with rapid development in the structural and functional diversity of the infant microbe community, establishing a mature, adult-like state of GM. The induction of complementary feeding and the gradual transition to the "family" diet is characterized by an increase of adult-associated microbes from the family Lachnospiraceae and Ruminococcaceae [24]. Maturation and differentiation are essential steps in GM establishment, which is why many researchers ask the question: When is the optimal time for reduction of breastfeeding and introduction of "adult" foods?

Laursen et al. [32] showed that besides the duration of breastfeeding, the composition of the complementary diet was also a significant determinant of GM development. The introduction of family foods containing high protein and fiber strongly influenced both microbial composition and GM alpha diversity. Intake of meats, cheeses, and Danish rye bread, rich in protein and fiber, were associated with increased alpha diversity [32]. Additionally, Matsuyama et al. [33] observed significant changes in the gut microbiota community, correlated with changes in the children's dietary pattern over a period of 12 months. They noticed differential effects on specific Firmicutes-affiliated lineages in response to intake frequency of processed or unprocessed foods and positive influence of intake of fortified milk supplemented with Bifidobacterium probiotics and prebiotics (synbiotics) on Bifidobacterium spp. [33].

Interestingly, an infant's GM may also be determined by maternal gestational diet through a vertical transfer of maternal microbes to infants during vaginal delivery and breastfeeding. This theory is confirmed by the study of Lundgren et al. [34], who identified distinctions in infant microbial community structure dependent on maternal fruit and milk intake during pregnancy, but this effect differs according to the delivery model. Additionally, reports are suggesting that transmission of commensal bacteria from mother to fetus is likely to occur prior to parturition [35]. Chu et al. [35] 
observed that independent of maternal body mass index, a maternal high-fat diet led to distinct changes in the neonatal gut microbiome at birth, and which persisted through 4-6 weeks of age.

The relationships between the maternal gestational diet, breastfeeding, formula feeding, weaning, and GM shaping underscore the importance of educating pregnant mothers on proper nutrition during pregnancy and lactation.

\subsection{Diet Composition and Gut Microbiota}

Different dietary patterns, in particular, the composition of macronutrients and micronutrients of the diet and nutritional sources of macronutrients, contribute to GM remodeling. Even short-term dietary changes (a few days) may modulate GM composition and actively affect the host metabolism [36].

\subsubsection{Carbohydrates}

Among the macronutrients, carbohydrates (CHOs) play the most crucial role in shaping the GM, and their effects on the bacterial community have been the best described. It has been noted that simple CHOs (e.g., sucrose, fructose) cause rapid deregulation in the composition of the GM and hence metabolic dysfunction in the host [20], while complex CHOs, specifically, certain "microbiota accessible carbohydrates" (MACs), are beneficial. Oligosaccharides, such as fructooligosaccharides (FOS) and galactooligosaccharides (GOS), have been termed prebiotic, and they represent complex CHOs with the most influence on the GM composition. Their role in promoting Bifidobacterium and Lactobacillus growth has been widely described [37,38]. The systematic review and meta-analysis (64 studies involving 2009 individuals) concerning the effect of dietary fiber interventions on gut microbiota composition in healthy adults conducted by So et al. [39] showed that dietary fiber intervention resulted in a higher abundance of Bifidobacterium spp. and Lactobacillus spp., as well as elevated fecal butyrate production compared with the low-fiber counter group. Additionally, both FOS and GOS significantly increased the count of both Bifidobacterium spp. and Lactobacillus spp. compared with the control, but did not affect microbial alpha diversity and abundances of other prespecified bacteria. Data from selected studies regarding the influence of digestible and non-digestible carbohydrates on GM establishment and functionality are shown in Table 1.

Table 1. Influence of digestible and non-digestible carbohydrates on gut microbiota (GM).

\begin{tabular}{|c|c|c|c|c|}
\hline Reference & Study Type & Population & $\begin{array}{c}\text { Dietary Sources of } \\
\text { Carbohydrate }\end{array}$ & Influence on Gut Microbiota \\
\hline $\begin{array}{l}\text { Fehlbaum et al. } \\
\text { 2018 [40] }\end{array}$ & in vitro study & $\begin{array}{l}\text { screening platform } \\
\text { (i-screen) } \\
\text { inoculated with } \\
\text { adult fecal } \\
\text { microbiota }\end{array}$ & $\begin{array}{l}\text { a different source of } \\
\text { dietary fiber (DF): FOS } \\
\text { (chicory root), inulin } \\
\text { (chicory root), alpha-GOS } \\
\text { (peas), beta-GOS (lactose), } \\
\text { XOS-C (corn cobs), XOS-S } \\
\text { (sugar cane fiber), and } \\
\beta \text {-glucan (oat flour) }\end{array}$ & $\begin{array}{l}\beta \text {-glucan induced } \uparrow \text { Prevotella } \\
\text { and Roseburia and } \uparrow \text { SCFA } \\
\text { propionate production. } \\
\text { Inulin and GOS, XOS induced } \\
\uparrow \text { Bifidobacteria } \\
\text { all DF had a prebiotic activity } \\
\text { with } \beta \text {-glucan being dominant }\end{array}$ \\
\hline $\begin{array}{c}\text { Do et al. } 2018 \\
\text { [41] }\end{array}$ & $\begin{array}{c}\text { animal } \\
\text { experimental } \\
\text { study }\end{array}$ & $\begin{array}{c}\text { eight-weeks-old } \\
\text { male C57BL/6J } \\
\text { mice }(n=36)\end{array}$ & $\begin{array}{l}\text { normal diet (ND), HGD } \\
\text { (high glucose diet), HFrD } \\
\text { (high fructose diet), or } \\
\text { HFD (high-fat diet) for } 12 \\
\text { weeks }\end{array}$ & $\begin{array}{c}\text { HGD and HFrD caused } \uparrow \\
\text { Akkermansia, } \downarrow \text { microbial } \\
\text { diversity ( } \downarrow \text { Bacteroidetes, } \uparrow \\
\text { Proteobacteria) vs. HFD group }\end{array}$ \\
\hline
\end{tabular}


Table 1. Cont.

\begin{tabular}{|c|c|c|c|c|}
\hline Reference & Study Type & Population & $\begin{array}{l}\text { Dietary Sources of } \\
\text { Carbohydrate }\end{array}$ & Influence on Gut Microbiota \\
\hline $\begin{array}{l}\text { Whelan et al. } \\
2005 \text { [43] }\end{array}$ & $\begin{array}{l}\text { a randomized, } \\
\text { double-blind, } \\
\text { crossover trial }\end{array}$ & $\begin{array}{l}\text { healthy subjects } \\
\qquad(n=10)\end{array}$ & $\begin{array}{l}\text { standard enteral formula } \\
\text { vs. formula supplemented } \\
\text { with FOS }(5.1 \mathrm{~g} / \mathrm{L}) \text { and } \\
\text { fiber }(8.9 \mathrm{~g} / \mathrm{L}) \text { as a sole } \\
\text { source of nutrition } \\
\text { for } 14 \text { days }\end{array}$ & $\begin{array}{l}\text { FOS/fiber formula led to } \uparrow \\
\text { Bifidobacteria and } \downarrow \text { Clostridia } \\
\text { and induced higher } \\
\text { concentrations of total SCFA, } \\
\text { acetate, and propionate }\end{array}$ \\
\hline $\begin{array}{l}\text { Martinez et al. } \\
\quad 2010[44]\end{array}$ & $\begin{array}{l}\text { a double-blind, } \\
\text { crossover trial }\end{array}$ & $\begin{array}{l}\text { heathy human } \\
\qquad(n=10)\end{array}$ & $\begin{array}{l}\text { crackers containing either } \\
\text { RS2 (resistant starch type } \\
\text { 2), RS4, or native stRS } \\
\text { types } 2 \text { (RS2) and } 4 \text { (RS4) } \\
\text { for } 3 \text { weeks }\end{array}$ & $\begin{array}{c}\text { RS4 but not RS2 induced } \\
\text { significantly, reversible } \uparrow \\
\text { Actinobacteria and Bacteroidetes } \\
\text { and } \downarrow \text { Firmicutes. } \\
\text { RS4 induced } \uparrow \text { Bifidobacterium } \\
\text { adolescentis and Parabacteroides } \\
\text { distasonis, } \\
\text { RS2 induced } \uparrow \text { proportions of } \\
\text { Ruminococcus bromii and } \\
\text { Eubacterium rectale }\end{array}$ \\
\hline $\begin{array}{l}\text { Davis et al. } \\
2011 \text { [45] }\end{array}$ & $\begin{array}{l}\text { single-blinded } \\
\text { study }\end{array}$ & $\begin{array}{l}\text { healthy human } \\
\text { subjects }(n=18)\end{array}$ & $\begin{array}{l}\text { GOS-containing products } \\
\text { with four doses }(0,2.5,5, \\
\text { and } 10 \mathrm{~g} \text { GOS) } \\
\text { for } 12 \text { weeks }\end{array}$ & $\begin{array}{l}\uparrow \text { Bifidobacterium (at the } \\
\text { expense of Bacteroides) with a } \\
\text { dose-dependent manner }\end{array}$ \\
\hline $\begin{array}{l}\text { Walker et al., } \\
2011[46]\end{array}$ & $\begin{array}{l}\text { randomized } \\
\text { crossover trial }\end{array}$ & $\begin{array}{l}\text { overweight adult } \\
\text { men }(n=14)\end{array}$ & $\begin{array}{l}\text { HRSD (high in resistant } \\
\text { starch diet), NPS (diet high } \\
\text { in non-starch } \\
\text { polysaccharides), WL } \\
\text { (reduced CHO diet) vs. } \\
\text { control diet } \\
\text { for } 10 \text { weeks }\end{array}$ & $\begin{array}{l}\text { HRSD } \uparrow \text { Ruminococcus bromii } \\
\text { and Eubacterium rectale }\end{array}$ \\
\hline $\begin{array}{l}\text { Hald et al. } 2016 \\
\text { [48] }\end{array}$ & $\begin{array}{c}\text { randomized } \\
\text { crossover study }\end{array}$ & $\begin{array}{c}\text { adults with } \\
\text { metabolic } \\
\text { syndrome }(n=19)\end{array}$ & $\begin{array}{c}\text { a diet enriched with AX } \\
\text { (arabinoxylan) and RS2 } \\
\text { (resistant starch type 2) vs. } \\
\text { low-fiber Western-style } \\
\text { diet } \\
\text { for 4-weeks }\end{array}$ & $\begin{array}{c}\text { AX, RS2 caused } \downarrow \text { total species } \\
\text { diversity, } \uparrow \text { heterogeneity of } \\
\text { bacterial communities both } \\
\text { between and within subjects, } \\
\text { induced } \uparrow \text { Bifidobacterium, } \uparrow \\
\text { total SCFAs, } \uparrow \text { acetate, } \uparrow \\
\text { butyrate, } \downarrow \text { isobutyrate, and } \downarrow \\
\text { isovalerate }\end{array}$ \\
\hline $\begin{array}{l}\text { Nicolucci et al. } \\
2017 \text { [38] }\end{array}$ & $\begin{array}{l}\text { double-blind, } \\
\text { randomized } \\
\text { placebo-controlled } \\
\text { trial }\end{array}$ & $\begin{array}{l}\text { children }(n=30 ; \\
7-12 \text { years) with } \\
\text { overweight/obesity } \\
\text { (>85th percentile of } \\
\text { BMI) but otherwise } \\
\text { healthy }\end{array}$ & $\begin{array}{c}\text { oligofructose-enriched } \\
\text { inulin }(\mathrm{OI}) ; 8 \mathrm{~g} / \text { day; } n=22 \text { ) } \\
\text { diet vs. maltodextrin } \\
\text { placebo diet (isocaloric } \\
\text { dose, } n=20) \\
\text { for } 16 \text { weeks }\end{array}$ & $\begin{array}{c}\downarrow \text { body weight z-score }(3.1 \%) \text {, } \\
\text { percent body fat }(2.4 \%) \text {, } \\
\text { percent trunk fat }(3.8 \%) \text {, and } \\
\text { IL-6, TG level in OI group } \\
\uparrow \text { Bifidobacterium spp. and } \downarrow \\
\text { Bacteroides vulgatus in the OI } \\
\text { group }\end{array}$ \\
\hline $\begin{array}{l}\text { Mardinoglu et al. } \\
\text { 2018 [49] }\end{array}$ & $\begin{array}{l}\text { short-term } \\
\text { intervention } \\
\text { study }\end{array}$ & $\begin{array}{l}\text { obese subjects with } \\
\text { non-alcoholic fatty } \\
\text { liver disease } \\
(n=10)\end{array}$ & $\begin{array}{l}\text { isocaloric low-CHOs diet } \\
(30 \mathrm{~g} / \mathrm{d}) \text { with increased } \\
\text { protein content by } 14 \text { days }\end{array}$ & $\begin{array}{l}\text { rapid reduction (after } 24 \mathrm{~h} \text { ) of } \\
\text { fiber-degrading bacteria, } \uparrow \\
\text { Lactococcus, Eggerrthella, and } \\
\text { Streptococcus } \downarrow \text { SCFAs level }\end{array}$ \\
\hline
\end{tabular}

Alpha-linked galactooligosaccharides (alpha-GOS), arabinoxylan (AX, beta-linked galactooligosaccharides (beta-GOS), carbohydrates (CHOs), dietary fiber (DF), HFD (high-fat diet), HFrD (high fructose diet), HGD (high glucose diet), HRSD (high in resistant starch diet), oligofructose-enriched inulin (OI), short chain fatty acid (SCFA), xylooligosaccharides from corn cobs (XOS-C), xylooligosaccharides from sugar cane fiber (XOS-S), normal diet (ND), a diet high in non-starch (NPS). 
Fruits, vegetables, and wholegrain cereals are the main sources of complex carbohydrates in the human diet [51]. However, plant cell wall polysaccharides and resistant starch (RS) are difficult to digest and absorb in the intestinal tract. Therefore, they undergo microbial breakdown and subsequent fermentation to the final products: SCFAs. Butyrate is mainly produced by Firmicutes, propionate is produced by Bacteroidetes, and acetate is made by most gut anaerobes [52]. Butyrate is the primary energy source for colonocytes and plays an important role in brain function and maintenance of the intestinal barrier. Propionate is a substrate for gluconeogenesis in the liver and, along with butyrate, promotes intestinal gluconeogenesis. Acetate and butyrate are substrates for fatty acid synthesis [53]. The SCFAs have multiple effects, including inhibition of histone deacetylase activity (HDAC) (butyrate), modulation of expression of peroxisome proliferator-activated $\gamma$ receptor (PPAR- $\gamma$ ), G-protein-coupled receptor 43 (GPR43; or free fatty acid receptor 2 (FFA2)) and GPR41 (or FFA3) (all three SCFAs), and of GPR109A (only butyrate). Acetate impacts intestinal antibody IgA responses, and butyrate inhibits the prototype pro-inflammatory signaling pathway (nuclear factor kappa B (NF-kB)). SCFAs also have roles in regulating inflammation and cancer [53].

Experimental studies have proven that regular consumption of fiber (especially the soluble fraction) in the optimal amount, i.e., about $30 \mathrm{~g}$ per day, is positively correlated with the production of butyrate by multiple bacteria, including Faecalibacterium prausnitzii, and members of the genus Clostridium and the genera Butyrivibrio and Eubacterium [54]. Adversely, in obese subjects with non-alcoholic fatty liver disease (NAFLD), a rapid rearrangement in the GM composition and, in consequence, in SCFAs production takes place within $24 \mathrm{~h}$ of reduction of carbohydrate (including DF) intake to $30 \mathrm{~g} /$ day [49].

A previous study has shown that a diet low in MACs contributes to a decrease in numerous specific bacterial taxa and reduces diversity, and this effect persists even after the reintroduction of MACs (Table 1) [40]. Since SCFAs regulate various pathways, the reduction in their production as a consequence of inadequate dietary fiber intake acts to deregulate energy balance and lipid and carbohydrate metabolism. Additionally, under conditions in which dietary polysaccharides are absent, GM use host mucus glycans as an alternative energy source. A study conducted by Desai et al. [55] using animal models showed that dietary fiber deprivation, and in consequence, erosion of the colonic mucus barrier, promoted greater epithelial access and enhanced inflammation and susceptibility to pathogens. A low intake of DF during a high-protein/low-CHO diet also shifts the GM metabolism toward the utilization of dietary and endogenously supplied proteins, causing elevated levels of cytotoxic and pro-inflammatory metabolites (such as branched-chain fatty acids, ammonia, amines, N-nitroso compounds, p-cresol, sulfides, indolic compounds, and hydrogen sulfide) [56].

\subsubsection{Proteins}

Proteins are an essential component of the human diet, customarily providing $10-20 \%$ of daily energy requirements. Products of protein GM degradation constitute a broad group of compounds, which include SCFAs, indoles, amines, phenols, thiols, hydrogen sulfide, $\mathrm{CO}_{2}$, and $\mathrm{H}_{2}$ [51]. The effects of dietary protein on GM have been observed in several studies. The first study in this area described that individuals who consumed a high beef diet had lower counts of Bifidobacterium adolescentis and increased abundance of Bacteroides and Clostridia when compared to those in a meatless diet counter group [57]. This study initiated a series of interventional and observational studies that described the effects of diets with different protein contents (low protein, high protein diet) and various sources of protein in the diets on the establishment of the GM (Table 2) [58].

A majority of previous studies have concluded that protein consumption positively correlates with overall microbial diversity, but there are significant differences in bacterial enterotypes between individuals preferring animal-derived proteins versus plant-derived proteins. Consumption of animal-based protein is associated with an increase in counts of bile-tolerant anaerobes, such as Bacteroides, Alistipes, and Bilophila $[59,60]$. This relationship has also been described by Filippo et al. [61] in a study comparing GM of Italian children with that of children from Burkina Faso. The study compared equally-caloric diets with a different proportion of animal protein and carbohydrate (DF) 
and revealed that despite individuals on a high-protein and low $\mathrm{CHO}$ diet losing weight, their GM changed unfavorably-the count of Roseburia and Eubacterium rectale and proportion of butyrate decreased [62]. The previous study also revealed that a high-protein diet affected the increase in Streptococcus, E. coli/Shigella, and Enterococcus (5.36-fold, 54.9-fold, and 31.3-fold, respectively) and a decrease in beneficial Faecalibacterium prausnitzii (by 3.5-fold) and Ruminococcus (by 8.04-fold) [63].

Table 2. Influence of different sources of proteins on GM.

\begin{tabular}{|c|c|c|c|c|}
\hline Reference & $\begin{array}{c}\text { Dietary Sources of } \\
\text { Proteins }\end{array}$ & Study Type & Population & Influence on Gut Microbiota \\
\hline $\begin{array}{l}\text { Meddah et al. } \\
2001[64]\end{array}$ & $\begin{array}{l}\text { whey protein, } \\
\text { duration of study }\end{array}$ & in vitro study & $\begin{array}{l}\text { simulator of the human } \\
\text { intestinal microbial } \\
\text { ecosystem (SHIME) }\end{array}$ & $\begin{array}{c}\text { increased Bifidobacterium and } \\
\text { Lactobacillus and decreased } \\
\text { Bacteroides fragilis and Clostridium } \\
\text { perfringens } \\
\text { increase in acetic acid, } \mathrm{CH}_{4} \text {, and } \\
\mathrm{CO}_{2} \text { production, suggesting } \\
\text { overgrowth of some anaerobic } \\
\text { bacteria }\end{array}$ \\
\hline $\begin{array}{l}\text { Świątecka et al. } \\
2011 \text { [65] }\end{array}$ & $\begin{array}{l}\text { glycated pea } \\
\text { protein } \\
\text { duration of study }\end{array}$ & in vitro study & $\begin{array}{l}\text { batch-type simulator } \\
\text { models imitating } \\
\text { human intestinal } \\
\text { conditions }\end{array}$ & $\begin{array}{l}\text { increased Bifidobacterium and } \\
\text { Lactobacillus } \\
\text { increased levels of the SCFAs }\end{array}$ \\
\hline $\begin{array}{l}\text { Butteiger et al. } \\
2016 \text { [67] }\end{array}$ & $\begin{array}{l}\text { soy protein vs. } \\
\text { milk protein (MPI) } \\
\text { duration of study }\end{array}$ & $\begin{array}{l}\text { animal } \\
\text { experimental } \\
\text { study }\end{array}$ & $\begin{array}{l}\text { 6- to 8-week-old, male } \\
\text { Golden Syrian } \\
\text { hamsters }(n=32)\end{array}$ & $\begin{array}{l}\text { reduced abundance of Bacteroides } \\
\text { and increased abundance of } \\
\text { Proteobacteria in MPI group }\end{array}$ \\
\hline
\end{tabular}

\subsubsection{Lipids}

Dietary lipids from plants and animals are a broad group of compounds that are a reserve source of energy for the human body and help determine its proper growth and development. The group encompasses fatty acids, including saturated (SFA), monounsaturated (MUFA), and polyunsaturated (PUFA) fatty acids, their derivatives, including mono-, di-, and triglycerides, and phospholipids, as well as sterols, such as cholesterol [69]. In a traditional, healthy diet, 30\% of fat content in balanced proportion SFA:MUFA:PUFA is recommended. Both the quantity and the quality of dietary lipids play a role in GM establishment (Table 3). In observational studies, it has been described that a diet enriched in MUFA and PUFA increases the Bacteroidetes:Firmicutes ratio and elevates numbers of lactic acid bacteria-Bifidobacteria and Akkermansia muciniphila. Conversely, SFA (specifically long-chain saturated fatty acids) promotes the growth of Bilophila and Faecalibacterium prausnitzii and causes a decline in numbers of Bifidobacterium, Bacteroidetes, Bacteroides, Prevotella, Lactobacillus ssp. [70-72]. The diet high in SFA influences the secretion of bile acid and boosts levels of bile acids in the intestine, including increased production of hydrophobic secondary bile acids (e.g., deoxycholic acid-DCA). DCA leads to changes in the composition and structure of GM. Elevated DCA has been described as a factor promoting atherosclerosis, diabetes, and other cardiometabolic diseases [73]. Additionally, it 
has been considered that SFA as an essential component of the lipid portion of lipopolysaccharide (LPS) of pathogenic bacteria activates an inflammatory cascade via toll like receptor 4 (TLR-4) [73]. The interventional study has provided evidence that although both a high-SFA diet or a diet with a high n-6 to n-3 PUFA ratio promote weight gain, only increased SFA consumption is related to insulin resistance, visceral adiposity, and intestinal permeability [74]. The differences between mice fed an HFD and n-6 PUFA diet or LFD and n-3 PUFA diet are also documented. Caesar et al. [75] compared the gut microbiota of mice fed with an HFD based on lard (SFA) or fish oil (n-3 PUFA) and noticed that diversity and counts of commensal Akkermansia muciniphila, Lactobacillus, and Bifidobacterium were higher in the mice that consumed fish oil. Additionally, in the mice that consumed lard, it was observed that the Toll-like receptor 4 (TRL-4) was activated, and hence there was increased inflammation in white adipose tissue (WAT). A study addressing the effect of nut consumption on shaping the microbial community has demonstrated that a high amount of walnuts in the diet (43 g/d) result in significant changes in composition and diversity in the GM by enhancing Ruminococcaceae and Bifidobacteria and decreasing Clostridium sp. cluster XIVa species [76]. Additionally, significant changes have been observed in some bacterial enzyme activities (increased $\beta$-galactosidase activity and reduced fecal $\beta$-glucuronidase, nitroreductase, and azoreductase activities) in response to the consumption of nuts [53]. Similarly, the beneficial effects of PUFA-rich nuts on GM have been observed in other studies $[77,78]$. The different microbial enterotypes have been described in the previous study regarding diet with milk fat (increased pro-inflammatory Bilophila wadsworthia) [79]. It should be noted that a systematic review conducted by Wolters et al. [80] within the MyNewGut project concluded that results of available interventional studies in humans did not suggest strong effects of different amounts and types of dietary fat on the intestinal microbiota composition. They noticed that high consumption of fat and SFA might unfavorably affect microbiota richness and diversity, and high MUFA diets might decrease total bacterial abundance, whereas PUFA probably did not affect GM richness and diversity [80].

Table 3. Influence of lipids on GM.

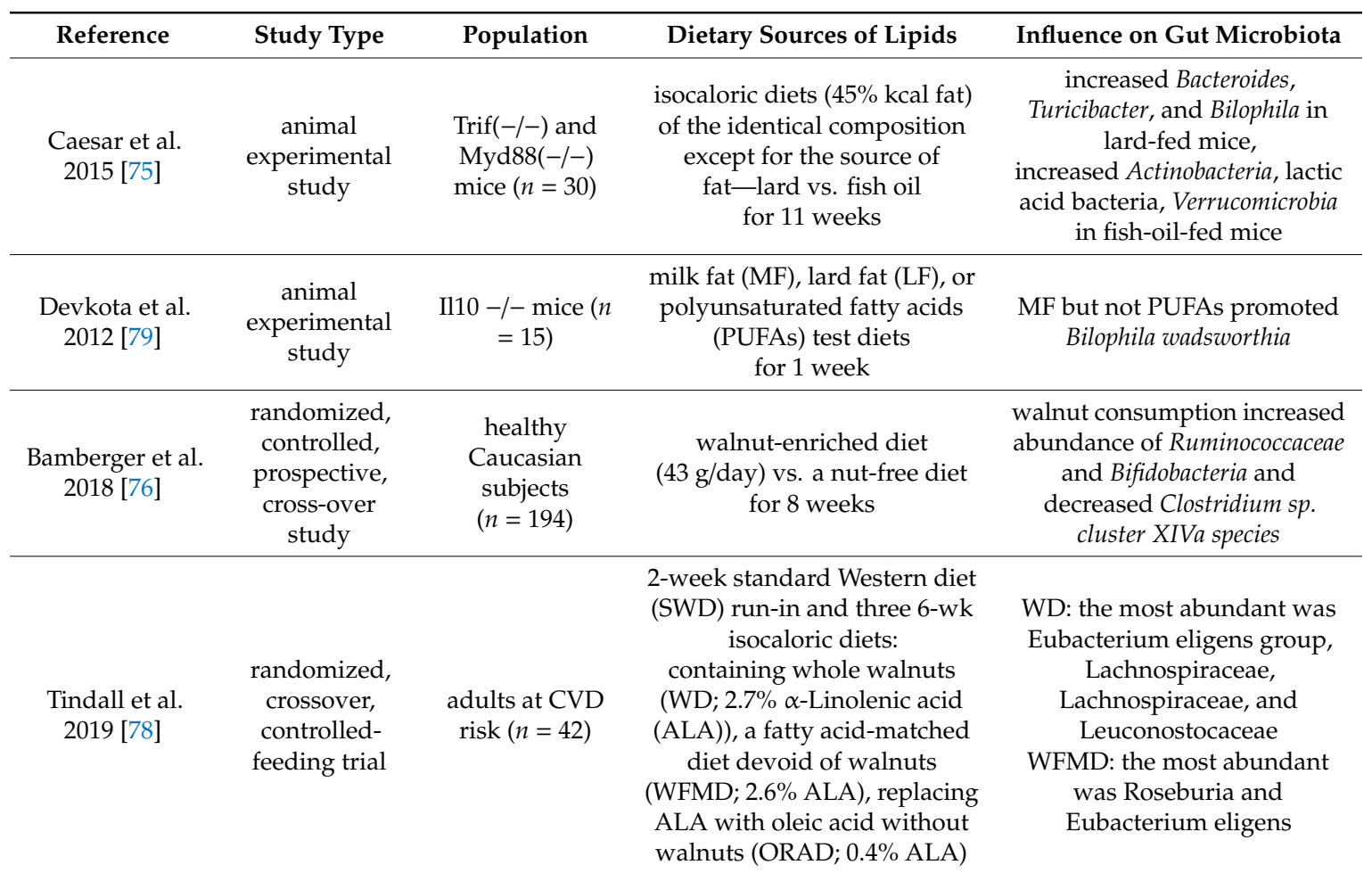

$\alpha$-Linolenic acid (ALA), cardiovascular disease (CVD), lard fat (LF), milk fat (MF), oleic acid diet (ORAD), polyunsaturated fatty acids (PUFAs), standard Western diet (SWD), whole walnuts diet (WD), walnuts free diet (WFMD; 2.6\% ALA). 


\subsubsection{Other Dietary Components and GM}

A beneficial microbial community in the gut is influenced by several additional but essential factors, such as intake of probiotics, the content of bioactive substances, such as polyphenols, in the diet, dietary supplementation of vitamins and minerals, and abuse of alcohol/tea/coffee/salt in the diet.

Dietary polyphenols include a broad group of substances (such as catechins, flavonols, flavones, anthocyanins, phenolic acids) with well-described antioxidant properties. In everyday diets, people consume polyphenols mainly from fruits and vegetables, tea, cocoa products, and red wine. Previous studies have demonstrated that polyphenols have a beneficial effect on GM by increasing the abundance of Bifidobacterium and Lactobacillus and elevating the production of SCFAs. Additionally, a reduction in pathogenic bacteria-Clostridium species (C. perfringens and Clostridium histolyticum) - has been detected in response to polyphenols intake [81].

Probiotics are defined as "live microorganisms which, when administered in adequate amounts, confer a health benefit on the host" [82]. They occur naturally in fermented foods containing lactic acid bacteria (fermented milk, yogurt). The influence of probiotic-containing foods on the increase in total bacterial load, promotion of Bifidobacteria and/or Lactobacilli and/or Streptococcus, and reduction in E. coli and Helicobacter pylori have been widely described in previous reviews $[83,84]$.

The evidence of selected studies concerning the influence of vitamins and minerals and the association between alcohol/salt/coffee/tea consumption and microbial community shaping is present in Table 4.

Table 4. Influence of selected dietary factors on GM.

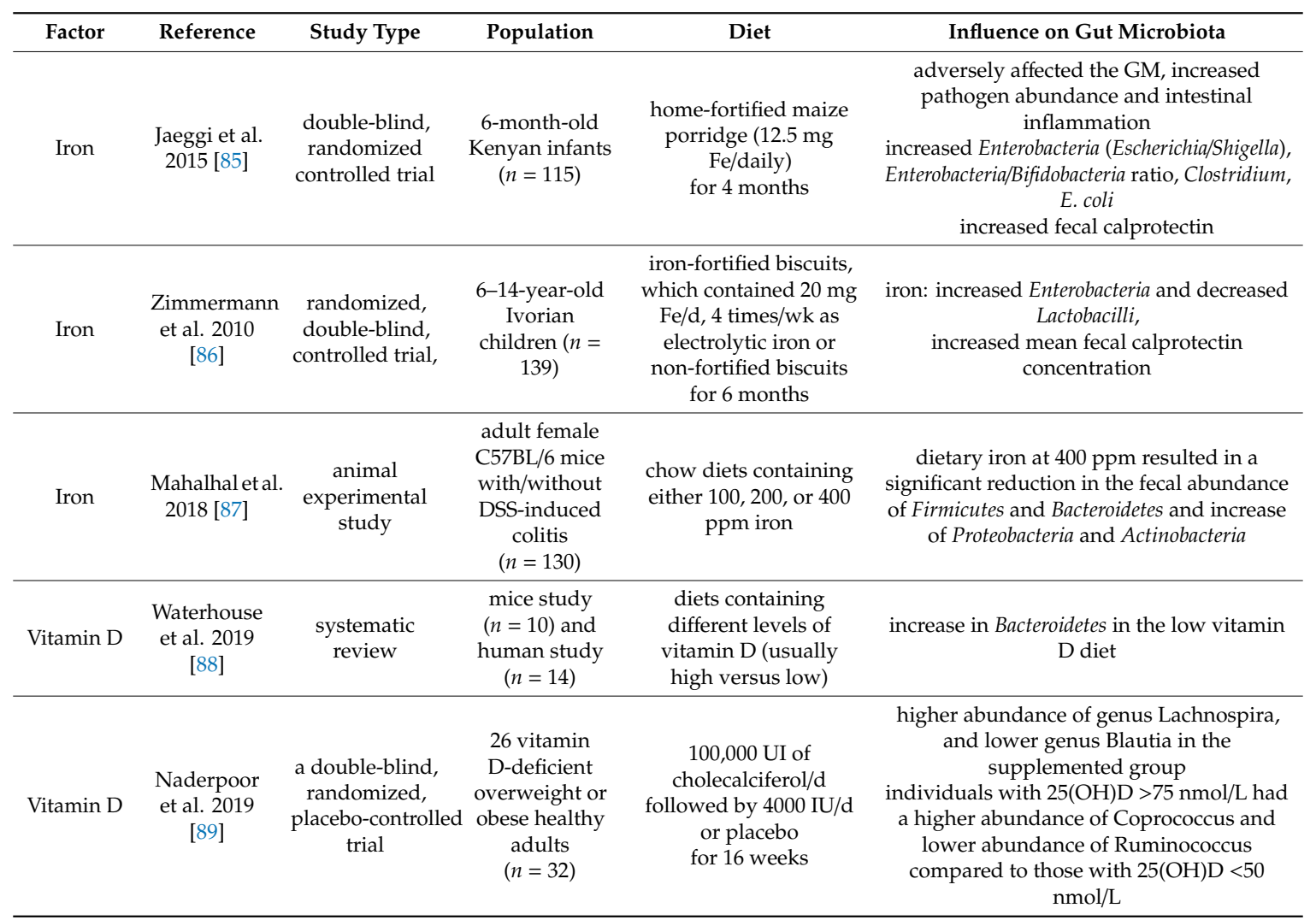


Table 4. Cont.

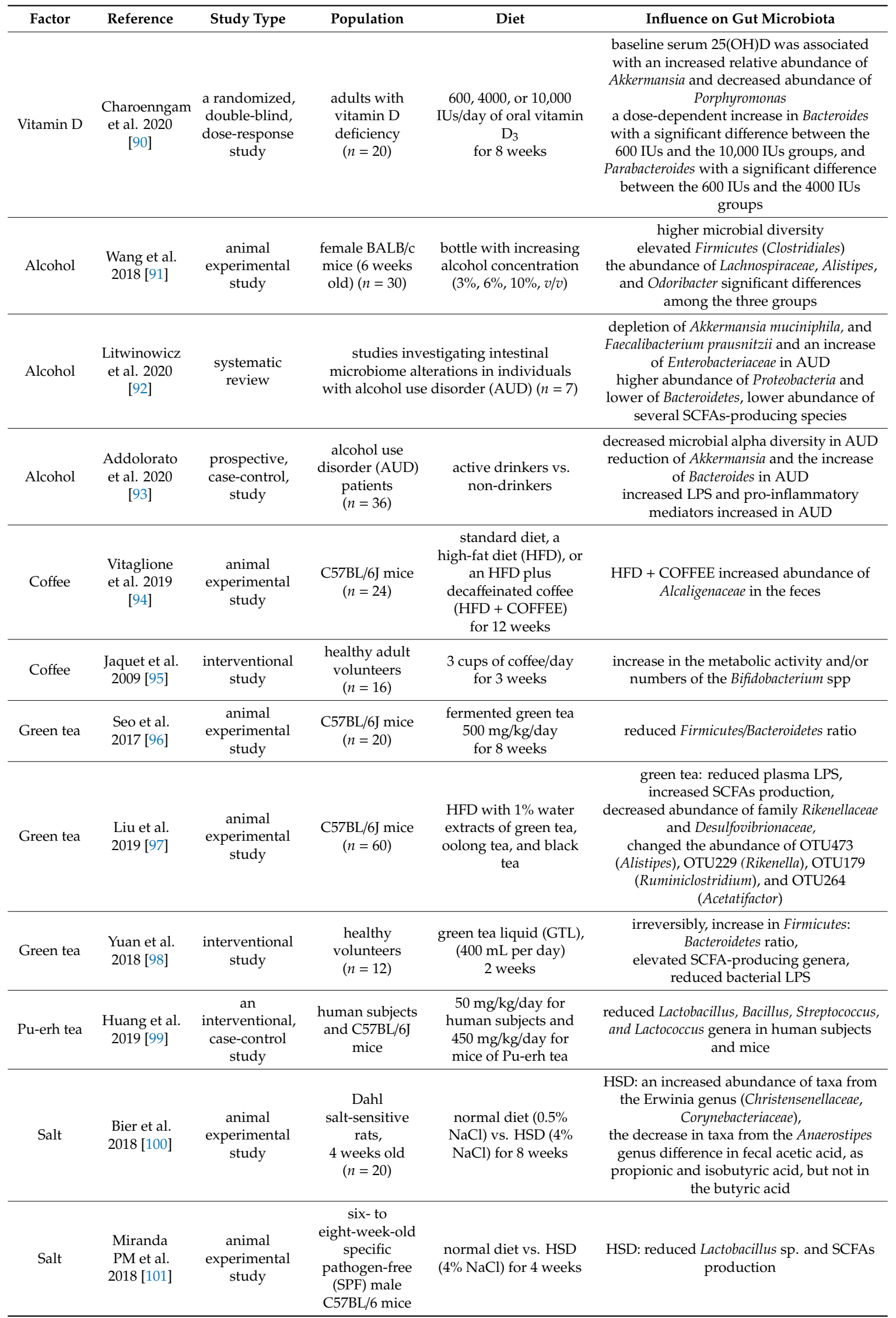


Table 4. Cont.

\begin{tabular}{|c|c|c|c|c|c|}
\hline Factor & Reference & Study Type & Population & Diet & Influence on Gut Microbiota \\
\hline Salt & $\begin{array}{l}\text { Wang et al. } \\
2017 \text { [91] }\end{array}$ & $\begin{array}{l}\text { animal } \\
\text { experimental } \\
\text { study }\end{array}$ & C57BL/6J mice & $\begin{array}{c}\text { low- or high-salt diets } \\
\text { (HSD) }(0.25 \text { vs. } 3.15 \% \\
\mathrm{NaCl}) \\
\text { for } 8 \text { weeks }\end{array}$ & $\begin{array}{c}\text { HSD increased Firmicutes/Bacteroidetes ratio, } \\
\text { and the abundances of genera } \\
\text { Lachnospiraceae and Ruminococcus }(p<0.05) \text {, } \\
\text { but decreased the abundance of } \\
\text { Lactobacillus }\end{array}$ \\
\hline Salt & $\begin{array}{l}\text { Wilck et al. } \\
2017 \text { [102] }\end{array}$ & $\begin{array}{l}\text { animal } \\
\text { experimental } \\
\text { study }\end{array}$ & $\begin{array}{l}\text { 10-week-old, } \\
\text { male C57BL6/J } \\
\text { mice }\end{array}$ & $\begin{array}{c}\text { normal salt }(0.5 \% \\
\text { sodium }) \text { or high-salt } \\
\text { diet }(4 \% \text { sodium }+1 \% \\
\text { in drinking water }) \text { ad } \\
\text { libitum } \\
\text { for } 14 \text { days }\end{array}$ & $\begin{array}{l}\text { HSD created a distinct gut microbiome } \\
\text { composition compared to the normal-salt } \\
\text { diet (analysis of Jensen-Shannon } \\
\text { divergence). } \\
\text { HSD increased Firmicutes:Bacteroidetes ratio }\end{array}$ \\
\hline
\end{tabular}

Alcohol use disorder (AUD), green tea liquid (GTL), high-fat diet (HFD), high-salt diet (HSD), liposaccharides (LPS), short chain fatty acids (SCFAs), specific pathogen-free (SPF).

\subsection{Dietary Pattern and Gut Microbiota}

Although the influence of macronutrients and micronutrients on the composition and activity of the bacterial community is well described, it should be noted that the final diet-gut microbiota relationship is the result of their interaction. For this reason, it is reasonable to analyze the importance of specific dietary patterns and eating behaviors in establishing the intestinal microbiota.

\subsubsection{Vegetarian and Vegan Diet and GM}

The GM composition (especially in the proportion of Bacteroidetes, Prevotella, and Ruminococcus) differs between individuals on vegan or vegetarian diets and omnivores, which has been well documented in previous studies [59]. Among the reasons for these changes are differences in bacteria directly consumed together with food, variations in $\mathrm{pH}$, GI tract transit time, and differences in the number of substrates supplied for bacterial fermentation from the diet [59]. A plant-based diet naturally rich in DF, especially MACs, has a beneficial effect on the microbiome by inducing the development of more diverse and stable microbial systems. A comparative study describing the GM composition of the children from Burkina Faso consuming traditional plant-based, high fiber diet versus European children consuming a Western diet has shown profound differences [61]. GM in Burkina Faso children is characterized by significantly higher diversity with enrichment of Bacteroidetes and depletion of Firmicutes and the presence of the genera Prevotella and Xylanibacter (responsible for cellulose and xylan fermentation), which are absent in the gut of European children. It has been reported that Prevotella-dominated microbiota produces 2-3 times more propionate than the Bacteroides-dominated microbiota, and the amounts and ratios of the SCFA in both the enterotypes are different [103]. Additionally, in children from Europe, GM patterns include a higher abundance of potentially pathogenic Shigella and Escherichia than in the Burkina Faso group. The lower presence of butyrate-producing bacteria on a low fiber and high meat diet, through negative changes in colonic $\mathrm{pH}$, promote the growth of pathogenic bacteria [54]. In 2017, De Filippo et al. analyzed microbial differences in small groups of children living in Burkina Faso $(n=11)$, of two groups of children living in different urban settings (Nanoro town, $n=8$; Ouagadougou city, $n=5$ ), and of a group of Italian children $(n=13)$ [104]. They observed that the introduction of animal-products (rich in fat and simple sugars) to the traditional African diet (rich in cereals, legumes, and vegetables) led to changes in microbiota profiles, but the microbiota of rural children retained a geographically unique bacterial reservoir (Prevotella, Treponema, and Succinivibrio), capable of degrading fiber and polysaccharides from vegetables. In children living in urban areas, these bacterial species were progressively outcompeted by bacteria more suited to the metabolism of animal protein, fat, and high sugar foods, similarly to Italian children. As a consequence, among the population of children from highly urbanized areas, a progressive reduction of SCFAs was observed. Significant differences in GM patterns have also been described between traditionally living Hadza (Tanzania) people and Italian industrialized society, with the former having the advantage of greater diversity and richness [105]. 
In addition to the above-described differences in the number of Prevotella bacteria, the vegetarian/vegan enterotypes differ from the omnivore enterotype by the number of Bacteroides and Ruminoccosus phyla. It has been reported that long-term animal-based diet positively correlates with the abundance of bile-tolerant microorganisms (Bacteroides, Alistipes, Bilophilia) and negatively with genera Firmicutes, which are able to degrade dietary plant polysaccharides (Roseburia, Eubacterium rectale, and Ruminococcus) [36]. An abundance of Bacteroides in response to a Western diet-high in animal products and low in fiber from fruits and vegetables-has been previously described [106].

Both animal and plant-based diets influence the Ruminococcus enterotype. Ruminococcus is responsible for the degradation of complex $\mathrm{CHO}$ (cellulose, RS) and plays a role in the conversion of animal-derived choline to trimethylamine (TMA). Previous studies have reported that an abundance of Ruminococcus is positively correlated with butyrate production, lower endotoxemia, lower arterial stiffness, and lower BMI [59].

In a study addressing the associations of short-term dietary changes, long-term nutritional habits, and lifestyle with gut microbiota, Klimenko et al. [107] reported that a higher intake of vegetables and fruits in the diet was associated with higher GM community diversity, but this effect was dependent on the initial microbiota state. Similarly, significant differences in the composition and diversity of the microbial community have been noticed in several studies [108-111].

In intervention studies involving the enrichment of the diet with fruit, vegetables, or other high-fiber products (such as products derived from whole grains), a favorable change in the composition and diversity of biota has been observed. A Danish study involving 123 non-obese and 169 obese subjects has shown that higher fruit and vegetable intake is associated with a high number of gut microbial genes that determine optimal bacterial richness. This study revealed that a calorie-restricted diet with increased fiber intake for six weeks led to an increase in microbial gene richness in the low microbial gene count (LGC) group, which remained significantly different from that of the high microbial gene count (HGC) group. The observed changes in microbial gene count affected the reduction of body fat and improvement in lipid and insulin levels and insulin sensitivity [60]. Evidence also suggests that GM established by a plant-based diet promotes lower production of secondary bile acids (DCA) and TMA and, therefore, reduces the risk of intestinal barrier dysfunction, inflammation, and liver cancer [112].

In conclusion, the available literature provides evidence that vegetarian and vegan diets are effective in promoting the optimal diversity and richness of beneficial bacteria (e.g., by increasing Prevotella taxa) and reduction in harmful metabolites (DCA, TMA), hence supporting both human GM and overall health.

\subsubsection{Mediterranean Diet (MD) and Gut Microbiota}

Adherence to a Mediterranean diet (MD) has been linked to a reduced incidence of obesity and metabolic syndrome and decreased mortality and morbidity in patients with CVD [113,114]. Growing experimental and clinical evidence also suggests that an MD contributes to a beneficial GM pattern. The traditional MD is characterized by a high content of polyphenol-rich products (extra-virgin olive oil, red wine, vegetable, grains, legumes, whole-grain cereals, nuts), a beneficial proportion of fatty acids (high MUFA and PUFA, low SFA), and low consumption of processed meat and refined sugars. A raft of previous studies has revealed that this eating pattern could positively affect gut microbial communities. Mitsiu et al. [115] described that individuals with higher Mediterranean diet scores had lower Escherichia coli counts, a higher Bifidobacteria to E. coli ratio, increased levels and prevalence of Candida albicans, and a higher molar ratio of acetate compared with subjects with low adherence. De Filippis et al. [116] reported that high-level consumption of plant foodstuffs consistent with an MD was associated with a beneficial microbiome-related metabolomic profile (higher Prevotella and certain fiber-degrading Firmicutes profiles, higher SCFAs production) in subjects ostensibly consuming a Western diet [116]. The increased intestinal SCFAs level in subjects on the MD diet is determined by high consumption of vegetables, fruits, and legumes, which are rich sources of complex and 
insoluble fiber-the major substrates for microbial production of SCFAs. Another study conducted in patients from the CORDIOPREV study has shown that consumption of a Mediterranean diet or a low-fat diet might partially restore the gut microbiome dysbiosis in obese patients with metabolic syndrome [117]. Positive associations between higher adherence to an MD diet and increased levels of the butyrate-producing species-Faecalibacterium prausnitzii and Clostridium cluster XIVa-were observed by Gutiérrez-Díaz et al. [118]. Additionally, they detected that lower adherence to the MD was linked with higher urinary trimethylamine N-oxide (TMAO) levels. Similarly, in the PREDIMED study, it has been noted that concentrations of five metabolites in the choline pathway (TMAO, betaine, choline, phosphocholine, and $\alpha$-glycerophosphocholine) in a group of individuals assigned to a Mediterranean diet are lower than those of a low-fat control diet group. The lower level of TMAO observed in individuals on an MD arises from the fact that in comparison to the WD, MD is characterized by significantly less (over $50 \%$ reduction) consumption of products (eggs, red meat, cheese) containing choline and L-carnitine, which are metabolized to TMA.

In conclusion, strong evidence has accrued that MD beneficially modulates gut microbiota by increasing the abundance of Bacteroidetes, Clostridium cluster XIVa, Faecalibacterium prausnitzii, Lactobacilli, and Bifidobacteria and decreasing the abundance of Firmicutes. This diet pattern positively affects the diversity and activity of various gut bacteria and increases the SCFAs level, and hence improves host metabolism. The mechanisms involved in establishing a beneficial GM in response to the MD diet are the effect of prebiotics on DF, the positive effect of polyphenols and n-3 PUFA, and a low intake of processed food.

\subsubsection{Western-Style Diet (WSD) and Gut Microbiota}

The Western-style diet (WSD) with its high intake of energy-dense, high fat/meat (and processed meat), high sugar, salt, alcohol, and high content of processed food is associated with an elevated risk of cardiovascular diseases. Numerous studies have also demonstrated the negative effects of this diet model on gut microbiota richness and function. Being high in animal-derived protein and low in vegetables and fruits, a WSD leads to a significant decrease in numbers of total bacteria and commensal Bifidobacterium and Eubacterium species. It is suggested that a WSD may be associated with irreversibly reduced microbial diversity and depletion of specific bacterial species because of their low content of MACs [106]. Characteristics of the WSD—the low intake of DF and increased consumption of fat (mainly SFA)-lead to increased penetrability and a reduced growth rate of the inner mucus layer and hence increase the susceptibility to infections [119]. The negative effects of a WSD on the intestinal microbiome can be attributed to not only a poor intake of DF and a high intake of fat and animal-derived proteins but also to a high content of ultra-processed food and harmful food additives (e.g., emulsifiers, non-caloric artificial sweeteners (NAS)) [120]. An analysis by Partridge et al. [121] suggested that emulsifiers contributed to alterations in the gut microbiota, with changes to the intestinal mucus layer, increased bacterial translocation, and an impact on the associated inflammatory response. The effect of ultra-processed food on gut microbiota deregulation was also described by Martinez et al. [122], Viennois, and Chassaing [123], Suez et al. [124]. A study conducted by Chassaing et al. [123] on the influence of synthetic dietary emulsifiers polysorbate 80 (P80) and carboxymethylcellulose (CMC) on the gut microbiota revealed that both P80 and CMC affected deconstruction in the GM and led to increased expression of bacterial inflammatory molecules, such as flagellin [125]. Suez et al. [124] described that high consumption of commonly used non-caloric artificial sweeteners (NAS) promoted glucose intolerance through compositional and functional alterations to the GM. The role of NAS (such as sucralose, acesulfame-K, neotame) in deregulating the gut microbiome and promoting chronic inflammation has also been highlighted in several other studies [126-128].

In summary, there is strong evidence that the Western-style diet causes disorders of the microbiota, intensifies the chronic inflammatory process, and consequently leads to the development of metabolic disorders and cardiovascular diseases. 


\subsubsection{Other Dietary Pattern and Dietary Habits and GM}

The growing interest in describing the relationship between diet-dependent alteration of the GM and host metabolism has resulted in several studies, assessing the impact of different alternative nutritional models or everyday dietary habits on the establishment of the intestinal bacterial ecosystem.

Several studies have demonstrated that a gluten-free diet (GFD) causes a reduction in Bifidobacterium spp. and an increase in Enterobacteriaceae and Escherichia coli $[129,130]$. A preliminary study, conducted by Sanz et al. [131], showed that the abundance of healthy gut bacteria decreased, while counts of unhealthy bacteria increased in parallel to reductions in the intake of polysaccharides after following the GFD for more than one month. Even a short-term GFD followed for four weeks has affected the microbiota, with a reduction in family Veillonellaceae (class Clostridia) being noticed [132]. Similarly, significant changes in the composition of the microbiota and deregulation in its functions have been observed in people following other alternative dietary patterns, including the ketogenic diet [133,134], paleo diet $[135,136]$, or intermittent fasting $[137,138]$ (Table 5).

Currently, it is generally considered that irregular eating habits, such as skipping breakfast, having dinner late, and late-night eating, contribute to obesity and other metabolic disorders. Increasing evidence suggests that these improper diet habits may also result in deregulation in the composition and physiological function of GM by negatively influencing the circadian rhythm [19].

Table 5. Influence of selected dietary patterns on GM.

\begin{tabular}{|c|c|c|c|c|}
\hline Reference & Study Type & Population & Diet & Influence on Gut Microbiota \\
\hline $\begin{array}{l}\text { Hansen et al. } \\
2018 \text { [139] }\end{array}$ & $\begin{array}{l}\text { randomized, } \\
\text { controlled, } \\
\text { cross-over trial }\end{array}$ & $\begin{array}{l}\text { healthy (non-celiac) } \\
\text { adult Danish } \\
\text { subjects }(n=60)\end{array}$ & $\begin{array}{l}\text { low-gluten diet } \\
\text { (LGD) }(2 \mathrm{~g} / \mathrm{d}) \text { vs. } \\
\text { high-gluten diet } \\
\text { (HGD) }(18 \mathrm{~g} / \mathrm{d}) \\
\text { for } 8 \text { weeks }\end{array}$ & $\begin{array}{l}\text { LGD reduced Bifidobacterium spp. } \\
\text { HGD decreased Dorea longicatena } \\
\text { (and another species of Dorea), } \\
\text { Blautia wexlerae, Lachnospiraceae, } \\
\text { Anaeostipes hadrus, } \\
\text { Eubacterium hallii }\end{array}$ \\
\hline $\begin{array}{l}\text { Bonder et al. } \\
2016 \text { [132] }\end{array}$ & $\begin{array}{l}\text { observational } \\
\text { study }\end{array}$ & $\begin{array}{l}\text { healthy volunteers } \\
\qquad(n=21)\end{array}$ & $\begin{array}{l}\text { gluten-free diet } \\
\text { (GFD) } \\
\text { for } 4 \text { weeks }\end{array}$ & $\begin{array}{c}\text { GFD decreased Veillonellaceae, } \\
\text { Ruminococcus bromii, and Roseburia } \\
\text { faecis, Victivallaceae, Clostridiaceae, } \\
\text { ML615J-28, Slackia } \\
\text { GFD increased a Coriobacteriaceae }\end{array}$ \\
\hline $\begin{array}{l}\text { Özkul et al. } \\
2019 \text { [138] }\end{array}$ & $\begin{array}{c}\text { pilot observational } \\
\text { study }\end{array}$ & $\begin{array}{l}\text { healthy adult men } \\
\qquad(n=9)\end{array}$ & $\begin{array}{l}\text { Islamic fasting (IF) } \\
\text { (17 h of fasting/day } \\
\text { for } 29 \text { days) }\end{array}$ & $\begin{array}{c}\text { IF increased abundance of } \\
\text { Akkermansia muciniphila and } \\
\text { Bacteroides fragilis }\end{array}$ \\
\hline $\begin{array}{l}\text { Xie et al. } 2017 \\
\text { [140] }\end{array}$ & $\begin{array}{l}\text { interventional } \\
\text { study }\end{array}$ & $\begin{array}{l}\text { children with } \\
\text { drug-resistant } \\
\text { epilepsy }(n=14)\end{array}$ & $\begin{array}{l}\text { ketogenic diet (KD) } \\
\text { for } 1 \text { week }\end{array}$ & $\begin{array}{c}\text { KD decreased the phylum } \\
\text { Proteobacteria (Cronobacter) and } \\
\text { increased the phylum Bacteroidetes } \\
\text { (Prevotella, Bifidobacterium, } \\
\text { Bacteroides) }\end{array}$ \\
\hline
\end{tabular}

Casual diet (CD), islamic fasting (IF), gluten-free diet (GFD), high-gluten diet (HGD), ketogenic diet (KD), low-gluten $\operatorname{diet}(\mathrm{LGD})$, Mediterranean diet (MD), modern paleolithic diet (MPD), paleolithic diet (PD), trimethylamine N-oxide (TMAO). 


\section{Gut Microbiota and Metabolic Disorders}

\subsection{Gut Microbiota Composition in Metabolic Disorders}

One of the most significant public health problems today is obesity, defined as a chronic accumulation of lipids in fat tissue. Obesity is determined by many factors, but the most frequent cause is a disbalance between the consumption of energy from food and drinks and energy expenditure. Growing evidence suggests that the disbalance may be a consequence of dysregulated gut microbiota [142]. In the context of the development of obesity, the bacterial microflora participates in many relevant areas, including digestion and absorption of nutrients, energetic homeostasis (energy harvest), maintaining tightness of the intestinal epithelium, metabolism of carbohydrates, lipids, and bile acids, regulating intestinal motility, and regulating the immune and hormonal system.

The first studies concerning the impact of GM diversity and activity on metabolic disorders, particularly obesity, were based on findings from animal models. It has been observed that germ-free mice (especially raised mice devoid of all microorganisms) have a lower fat mass content than conventional mice, even though germ-free mice consume $29 \%$ more food [143]. Additionally, Bäckhed et al. [143] found a $60 \%$ increase in body fat mass and insulin resistance in adult germ-free mice within 14 days after colonization with GM from conventionally raised animals, despite having a reduced food intake [143]. It has also been noted that germ-free mouse with the obesity-resistance phenotype fed a high-fat diet (HFD) consumes fewer calories and has increased excretion of lipids, while an HFD in mice with normal microbiota contributes to weight gain, obesity progression, worsening in insulin sensitivity and inflammatory changes in the small intestine [144].

Upon investigating the cause of these phenomena, it has been discovered that GM composition differs between slim and obese mice. In comparison with lean mice, the microbiota of mice with obesity is characterized by a lower abundance of Bacterioidetes and a higher number of Firmicutes [142]. Similarly, differences in GM composition have been observed between obese and lean human subjects, with an elevated Firmicutes to Bacteroidetes ratio, and a higher proportion of Actinobacteria in obese subjects, and a reduced diversity and altered representation of bacterial genes and metabolic pathways [145]. Riva et al. [145] reported that obesity was associated with elevated levels of Firmicutes, such as Ruminococcaceae, and depleted levels of Bacteroidetes, such as Bacteroidaceae and Bacteroides. The Danish study observed that individuals with lower microbial gene count (LCG) were characterized by obesity, insulin resistance, adiposity, dyslipidemia, and a worse inflammatory status [146]. The obese gut microbiota phenotype is characterized by genes that participate in energy harvest and metabolism, specifically genes responsible for expressing enzymes that breakdown potentially indigestible complex plant polysaccharides to produce SCFAs. The systematic review has included seven human clinical studies with a total of 246 obese cases and 198 healthy controls and has shown that subjects with obesity have higher fecal levels of acetate, propionate, and butyrate SCFAs, as compared with lean controls [147]. The higher microbial capability to oxidize CHO in obese and the influence of SCFA on body fat partitioning were noticed by Goffredo et al. in children and adolescents [148]. They reported that a higher concentration of fasting plasma SCFA was associated with the percent total body fat, visceral fat, and positively predicted the changes in adiposity. What's more, the level of SCFAs was correlated with rates of de novo lipogenesis [148].

Dysregulated GM composition and functionality have also been described in patients with type 2 diabetes. Karlsson et al. [149] noticed that individuals with T2D, which could be considered a complication of obesity, had a lower abundance of fiber-degrading bacteria. Larsen et al. [150] described the reduction in phyla Firmicutes and Clostridia and the increase in Bacteroidetes to Firmicutes ratio, as well as an increased Bacteroides-Prevotella ratio in patients with T2D. In other studies, the decrease in butyrate-producing bacteria (Akkermansia muciniphila, Roseburia intestinalis, and Faecalibacterium prausnitzii), Haemophilus and Lactobacillus and an increase in Desulfovibrionaceae spp and various opportunistic pathogens (Clostridium spp., Bacteroides caccae) have been observed [151-153]. The significantly elevated abundance of Proteobacteria had been described by Amar et al. [154] as an 
independent marker of the risk of insulin resistance and diabetes in humans. It had also been observed that dysregulation in gut microbiota composition leading to impairment in gut integrity and metabolic endotoxemia was one of the leading factors in insulin resistance and the development of T2D. In an animal model, intravenous administration of lipopolysaccharides is a triggering factor, leading to weight gain and insulin resistance [155]. The same mechanism involving GM dysbiosis, an elevated level of circulating LPS, and the promotion of T2D has been elucidated in humans [156]. On the other hand, intervention with the use of oligofructose and long-chain inulin or with B-glucans has shown that along with an improvement in GM, positive changes in glucose metabolism are also noticed [157]. Nonetheless, microbiota functionality in subjects with T2D differs from that of people with normal weight. There has also been observed enriched membrane transport of sugars and branched-chain amino acids, increased sulfate metabolism products, reduced butyrate synthesis, and changes in the metabolism of cofactors and vitamins [151].

Another metabolic disorder associated with obesity is dyslipidemia. Dyslipidemia is defined as an elevation of circulating triglycerides (greater than $1.7 \mathrm{mmol} / \mathrm{L}(150 \mathrm{mg} / \mathrm{dL})$ ) or a reduction in circulating high-density lipoprotein (HDL) (less than $1.0 \mathrm{mmol} / \mathrm{L}(40 \mathrm{mg} / \mathrm{dL}$ ) in men and less than $1.3 \mathrm{mmol} / \mathrm{L}$ $(50 \mathrm{mg} / \mathrm{dL})$ in women), which contribute to the development of atherosclerosis and cardiovascular disease [158]. Previous studies have observed that GM in individuals with impaired lipid metabolism differs from that of healthy humans. Cotillard et al. [60] noted that the reduced microbial richness commonly observed in obese patients was also linked with increased total serum cholesterol and serum triglycerides (TG). Similarly, Le Chantelier noticed higher levels of TG in individuals with low microbial gene counts vs. those with high microbial gene counts [146]. Previous studies have not clearly defined the microbiota pattern characteristic of patients with dyslipidemia. By analyzing the composition of the microbiota of patients with symptomatic atherosclerosis, Karlsson et al. [149] observed a higher abundance of the genus Collinsella and a lower abundance of Eubacterium and Roseburia compared with healthy controls. Deregulation in gut microbiota composition (decreased phylum Bacteroidetes and increase in Lactobacillales) in patients with coronary artery disease (CAD) has also been revealed [159]. Additionally, a study with mice fed a high-fat high-cholesterol diet and supplemented with Lactobacillus curvatus and/or Lactobacillus plantarum has shown that commensal probiotic bacteria play important roles in normalizing lipid metabolism. In this study, Lactobacillus curvatus and/or Lactobacillus plantarum reduced cholesterol in plasma and liver and reduced the accumulation of hepatic triglycerides [160]. A comparable, positive anti-obesity and lipid-lowering effect of Bifidobacterium spp has been described by An et al. in obese rats fed a high-fat diet [161]. As in the case of insulin resistance, the decrease in LPS concentrations in response to infusion of polymyxin B has improved the markers of lipid metabolism and fatty hepatitis in mice [162].

\subsection{The Mechanism Underlying Gut Microbiota-Related Metabolic Disorders}

The alteration of microbiota composition and functionality may stimulate the development of metabolic disorders via several mechanisms involving increased energy harvest from the food, increased gut permeability leading to metabolic endotoxemia and its consequences, alterations in bile acid metabolism and G-protein-coupled bile acid receptor (FTR/TGR5) signaling, and influence of microbial metabolites: SCFAs, TMAO, indoles, LPS on various metabolic pathways.

\subsubsection{Role of SCFAs in Energy Harvest}

Metabolic functions of SCFAs produced by microbial fermentation are essential in human energy homeostasis and, therefore, may significantly influence the development of obesity, insulin resistance, type 2 diabetes, and lipid disorders. SCFAs act as both an energy substrate and as signaling molecules, influencing lipogenesis, oxidation of fatty acids, fat storage, and gluconeogenesis [163]. SCFAs increase lipogenesis, i.e., they increase triglycerides, and inhibit the inhibitor of lipoprotein lipase in the small intestine, which results in inhibition of fatty acid release from triglycerides, and hence promotes the cellular uptake of triglycerides, resulting in increased fat storage. 
The SCFAs acetate, propionate, and butyrate, which are found at an approximate molar ratio of 60:20:20, respectively, are an essential energy source and source of nutrition for the intestinal epithelium. Because $95 \%$ of SCFA are absorbed in the intestinal lumen, their elevated circulating plasma concentration, which characterizes individuals with obesity, provides an additional energy source, and in consequence, promotes de novo hepatic lipogenesis. It has been estimated that the increased rate of SCFA production observed in obese humans contributes at least $10 \%$ of overall energy intake (up to approximately $200 \mathrm{kcal} /$ day). This "energy storage hypothesis" has been confirmed in several studies in the human population $[148,164,165]$.

SCFAs also act as signaling molecules and specific ligands for $G$ protein-coupled receptors. GPR41 and GPR43 regulate the secretion of anorectic hormones peptide YY (PYY) and production of insulinotropic intestinal hormones (incretins; glucagon-like peptide 1-GLP-1, GLP-2). These are currently regarded as the main factors determining postprandial insulin secretion and pancreatic $\beta$-cell function [106]. GLP-1 is known to have beneficial effects on glucose metabolism, while GLP-2 has been shown to improve the integrity of the intestinal epithelial tight junction [155]. PYY and its co-secreted GLP-1 play an important role in the endocrine regulation of appetite and satiety. Increased PYY secretion normally inhibits gut motility, accelerates the intestinal passage, and, therefore, reduces calorie extraction from the diet. Gpr41 also mediates SCFA-induced synthesis of leptin, an adipocytokine with pleiotropic effects on appetite and energy metabolism [166]. Stimulation of Gpr43 by SCFAs increases the differentiation of peroxisome proliferator-activated receptor-gamma (PPAR $\gamma$ ) and also reduces lipolysis, which leads to the development of adipose tissue accumulation. A recent study has shown that Gpr43-/- mice are resistant to diet-induced obesity and insulin resistance, at least partly due to Gpr43-regulated energy expenditure [167]. Furthermore, gut microbiota also affects the energy harvest by activating carbohydrate responsive element-binding protein (ChREBP) and sterol responsive element-binding protein (SREBP-1). In consequence, increased de novo lipogenesis is promoted in adipose tissue and liver [168]. The SCFAs are involved in lipid oxidation and energy expenditure also by their influence on the activation of the AMP-activated protein kinase (AMPK) in adipose tissue and skeletal muscles and regulation of peroxisome proliferator gene (PPAR). AMPK activates acetyl-CoA carboxylase (ACC) and carnitine-palmitoyltransferase I (CTP1) - two enzymes responsible for mitochondrial fatty acid oxidation. SCFA-induced activation of PPAR $\gamma$ modulates lipid metabolism through increased energy expenditure and decreased liver triglyceride accumulation. It has been described that germ-free mice have higher levels of phosphorylated AMPK in muscle and liver than conventional mice, and this determines their better control of energy expenditure [143].

However, there have been some mixed results concerning the relationship between SCFAs and obesity. For example, in some interventional studies, a positive correlation between SCFA supplementation and weight loss and insulin sensitivity by stimulating PYY and GLP-1 have been observed [169]. In light of these studies, the question arises whether the role of SCFAs in the development of obesity is dose-dependent (SCFAs at pharmacological doses vs. SCFAs in amounts produced during fermentation) and whether it is likely that an elevation in SCFAs in obese subjects might be a consequence, and not the cause, of an energy hyperalimentation, and might be a mechanism of defense against energy accumulation. It is suggested that despite a high level of SCFAs in obese individuals, they have become unresponsive to the regulatory effect of SCFAs on appetite and energy expenditure.

\subsubsection{Metabolic Endotoxemia}

The additional mechanism linking dysregulation of the GM and metabolic disorders is increased intestinal permeability, which induces metabolic endotoxemia and initiates an inflammatory cascade. In physiological conditions, the integrity of enterocytes is maintained by tight junctions, gap junctions, and desmosomes. In the dysbiosis state, there is an abnormal synthesis of proteins stabilizing tight junctions, such as zonulin-1 and occludin. As a consequence, the translocation of allergens and other toxic substances, including bacterial lipopolysaccharides LPS (endotoxin derived from the cell wall of gram-negative bacteria), from the intestinal lumen to the bloodstream is promoted. Cani et al. [170] in 
an animal model study noted that in response to an HFD, the plasma LPS level increased. The higher LPS concentration is associated with the development of obesity and insulin resistance [171]. On the other hand, an increased LPS level and obesity have been observed in mice fed a control diet after LPS infusion. In humans, it has been proven that patients with obesity, insulinresistance (IR), or type 2 diabetes (T2DM) have increased plasma concentrations of LPS compared to a healthy counter group [155].

The high concentration of LPS in circulation activates Toll-like receptors 4 (TLR-4) and nucleotide-binding oligomerization domain (NOD) expression and initiates low-grade inflammation, which ultimately contributes to obesity and development of metabolic disorders. LPS also activates inflammasomes, leading to maturation of interleukin-1 $\beta$ (IL-1 $\beta$ ) and IL-18, which are proinflammatory cytokines. Previous studies have reported an association of the NOD-, LRR- and pyrin domain-containing protein 3 (NLRP3) inflammasome with metabolic disorders, such as obesity and/or type 2 diabetes and insulin resistance [172].

The dysbiosis is closely associated with disturbances in $\mathrm{T}$ reg and Thelper proportion. The negative influence of endotoxemia on obesity and pathogenesis of metabolic disorders is also implicated in inflammatory cytokine overproduction in adipocytes, reduced adiponectin synthesis, increased secretion of leptin and resistin, and in consequence, elevated insulin-like growth factor-IGF-1 and IGF-2. Increased circulation of LPS has linked also with exacerbating triglycerides' accumulation in adipose tissue and muscle because it suppresses the fasting-induced adipose factor (FIAF). FIAF or angiopoietin-like protein 4 is a circulating lipoprotein lipase (Lpl) inhibitor produced by the intestine, liver, and adipose tissue. A previous study has demonstrated that introducing a gut microbiota to germ-free mice suppresses expression of FIAF in the gut epithelial cells and, therefore, leads to a higher adipocyte Lpl activity. As a consequence, there is an increased deposition of triglycerides in adipocytes and greater fat storage. A study in germ-free knock-out FIAF mice has shown that high-fat/high-carbohydrate diet affects obesity, which proves that FIAF plays a pivotal role in microbial regulation of energy harvest [143].

\subsubsection{Bile Acid Metabolism}

Primary bile acids, cholic acid, and chenodeoxycholic acid are synthesized in the liver as final degradation products of endogenous cholesterol. Primary bile acids play a critical role not only in the digestion and absorption of dietary lipids and fat-soluble vitamins, but they also affect intestinal barrier permeability and the inflammatory response. As signaling molecules, they regulate energy metabolism and lipid and glucose metabolic pathways. The bile acids are stored in the gallbladder, but in response to food ingestion, they are excreted into the duodenum, where they participate in the emulsification of dietary lipids. About $95 \%$ of the total primary bile acids are reabsorbed from the ileum to the liver, and the remaining $5 \%$ is deconjugated, dehydroxylated, and epimerized to secondary bile acids [173] Several molecular mechanisms regulate the enterohepatic circulation of bile acids, but the most important receptors for bile acid synthesis are farnesoid X receptor (FXR) and Takeda G-protein-coupled receptor (TGR5), which regulate diverse metabolic pathways in the host [174]. Binding bile acids to FXR activates transcription of genes participating in the regulation of bile acid reabsorption, including IBABP (ileal bile acid-binding protein), organic solute and steroid transporter $\alpha$ and $\beta(\mathrm{OST} \alpha / \beta)$, a growth factor for fibroblasts (fibroblast growth factor 19-FGF19), and short heterodimer partner (SHP). By the induction of the FXR-dependent expression of SHP and FGF15/FGFR4, the bile acids maintain a balance between the synthesis of bile acids and entero-hepatic circulation of bile acids. Moreover, FXR is involved in regulating lipid metabolism, specifically very low density lipoprotein (VLDL) and triglyceride synthesis and utilization, and control of hepatic de novo lipogenesis [175]. Previous studies have described the relationship between bile acids and glucose metabolism, suggesting the role of FXR activation in reducing serum glucose and improving insulin sensitivity [176,177]. FXR via small heterodimer partner (SHP) and stimulation by FGF-19 increases glycogen synthesis and reduces gluconeogenesis [177]. A role of FXR activation in glucose-induced 
insulin transcription and secretion has been proposed [178]. Additionally, it has been shown that FXR also plays an anti-inflammatory role and maintains the integrity of the intestinal barrier, preventing bacterial translocation in the digestive tract.

Takeda G-protein-coupled receptor (TGR5) is expressed in brown adipose tissue and muscle. Similar to FXR, TGR5 not only participates in the regulation of bile acid metabolism but also is a factor triggering human energy homeostasis and glucose and lipid metabolism. TGR5 activation promotes energy expenditure by its influence on the conversion of inactive thyroxine (T4) to active tri-iodothyronine (T3). In addition, TGR5 signaling induces GLP-1 release from L-cells, resulting in improved liver function and enhanced glucose tolerance [175].

The relationship between the bile acids and the intestinal microbiota is bidirectional. Both bile acids are an essential modulator of the microbial intestinal community, yet the composition of GM affects the proportion and amount of synthesized bile acids. It has been proposed that the conversion of primary to secondary bile acids is dependent on GM, and the type of secondary bile acids produced is determined by diet and the condition of the GM [175]. On the other hand, because different bile acids affect FXR in different ways (as an agonist or antagonist), the dysregulation in GM may lead to the impairment of host metabolism. The role of FXR in changing the gut microbiota composition and hence increasing adiposity has been proven in several animal studies [176,177]. Parséus et al. [178] in a study with germ-free (GF) and conventionally-raised (CONV-R) wild-type and Fxr-/- mice fed an HFD showed that microbiota-induced weight gain, hepatic steatosis, and inflammation were dependent on FXR signaling. Jiang et al. [179] reported that treatment of obese mice with glycine- $\beta$-muricholic acid (Gly-MCA) inhibited FXR signaling in the intestine and, therefore, improved metabolic parameters.

\subsubsection{Trimethylamine N-Oxide (TMAO)}

In the context of metabolic disorders and CVD, a strong relationship between gut microbiota dysbiosis and increased level of trimethylamine N-oxide (TMAO) has also been described. The gut microbiota metabolizes choline, phosphatidylcholine, and L-carnitine to trimethylamine (TMA). TMA is further transformed into trimethylamine $\mathrm{N}$-oxide (TMAO), which may promote increased atherosclerosis through mechanisms related to lipid metabolism and inflammation. It has been reported that subjects with atherosclerosis have elevated levels of circulating TMAO compared with healthy controls [180]. It has also been noted that elevated levels of TMAO are strongly associated with type 2 diabetes. The link between the gut microbiota-initiated trimethylamine-N-oxide (TMAO)-generating pathway and obesity and the beiging of white adipose tissue were described by Schugar et al. [181]. Hepatic flavin monooxygenase 3 (FMO3) is involved in the oxidation of TMA to TMAO in the liver. The experimental study has demonstrated that knockdown or genetic deletion of FMO3 has an anti-obesity effect. The expression of FMO3 is regulated by bile acid-activated FXR, and this relationship shows how interconnected are the pathways, linking intestinal dysbiosis and the promotion of metabolic diseases [182].

\subsubsection{Tryptophan-Derived Metabolites}

Tryptophan (Trp) is one of the essential aromatic amino acids supply from nutritional sources. About $4 \%$ to $6 \%$ of tryptophan is metabolized by GM into indican, indole or indole acid derivatives, skatole, and tryptamine [183]. The gut bacteria-derived indoles produced from tryptophan are a key modulator of host physiological and pathological pathways and hence may contribute to the cardiovascular, metabolic, and brain disorders [184]. The metabolism and biological effects of gut bacteria-derived indoles have been widely reviewed in several publications [184-186]. Indole propionic acid (IPA) is a metabolite produced by a small group of bacteria (especially Clostridium sporogenes) from dietary tryptophan. Previous studies have provided evidence that IPA plays an important role in intestinal barrier stabilization, antioxidant defense, and has neuroprotective effects [184]. The study conducted by Dodd et al. [187] in genobiotic mice inoculated with wild-type C. sporogenes showed that serum level of IPA was related to intestinal permeability and immune activation in a pregnane $X$ receptor 
(PXR)-dependent fashion. The previous study comparing differences in gut microbiota-dependent metabolites between GF and conventionally raised mice contrary to mice fed an high-fat diet (HFD) or low-fat diet (LFH) revealed that indole-3-acetate (I3A) and tryptamine were depleted under an HFD. Both metabolites, especially I3A, modulate inflammatory responses by decreased fatty-acid- and LPS-stimulated release of pro-inflammatory cytokines and chemokine [188].

\subsubsection{The State-of-Art: Microbiome-Based Treatment}

The growing body of reports describing the diet-GM-host health relation has resulted in researches concerning the use of microbial remodeling strategies in the treatment of metabolic diseases. The recent systematic review on six RCTs study conducted by Tenorio-Jiménez et al. [189] evaluated that the probiotics intake in patients with MetS might improve some clinical parameters, such as body mass index, blood pressure, glucose metabolism, lipid profile, and inflammatory biomarkers, but these beneficial effects seem to be clinically non-relevant [189]. However, it should be emphasized that the available data are still insufficient to recommend the supply of probiotics and/or prebiotics to all patients suffering from metabolic disorders explicitly. The rationalization of the use of probiotic-based strategies in the treatment of obesity and co-existing metabolic disorders requires the use of targeted types and strains of bacteria or/and their combinations, as well as standardization of dose, time, and form of their supply. Identifying these elements seems to be critical to future research into the use of probiotics in the treatment of metabolic disorders. The personalized diet recommendation based on GM or using metabolite supplementation also may successfully modify various metabolic pathways and hence affect improvement in human health [190].

\section{Conclusions}

Long term dietary pattern appears to have a pivotal influence on GM composition and functionality and hence on host metabolism. Proper nutrition, defined as a calorie-balanced diet, with adequate fruit and vegetable intake, rich in dietary fiber, with healthy fats (MUFAs and PUFAs), and a predominance of plant-derived proteins seem to be the best way to promote GM diversity and activity. Previous studies in animals and humans have observed that human GM differ between obese and lean individuals or in individuals with metabolic disorders. The deregulation in gut microflora predisposes to impairment of host metabolism in many ways, including the bacterial influence on energy harvest from food, damage in intestinal epithelium tightness leading to metabolic endotoxemia, and alteration in the metabolism of carbohydrates, lipids, and bile acids. Therapies targeting GM dysbiosis may, in the future, be a promising tool in support of the treatment of patients with several diseases, such as obesity, dyslipidemia, insulin resistance, or type 2 diabetes. In-depth knowledge of connections between GM establishment, metabolism, and human health will allow targeting microbiome reprogramming for the prevention and treatment of metabolic diseases in the future. The manipulation of microbiota-derived metabolites and their pathways can be helpful in exploring novel, individualized, and efficient treatment modalities for various human disorders.

Author Contributions: Conceptualization, M.M., M.S., and P.B.; methodology, M.M., M.S., and P.B.; formal analysis, M.S.; investigation, M.M. and P.B.; data curation, M.M. and M.S.; writing-original draft preparation, M.M.; writing-review and editing, M.M. and M.S.; visualization, M.M. and M.S.; supervision, P.B.; project administration, P.B.; funding acquisition, P.B. All authors have read and agreed to the published version of the manuscript.

Funding: This research received no external funding.

Conflicts of Interest: The authors declare no conflict of interest. 


\section{References}

1. Chong, P.P.; Chin, V.K.; Looi, C.Y.; Wong, W.F.; Madhavan, P.; Yong, V.C. The microbiome and irritable bowel syndrome-A review on the pathophysiology, current research and future therapy. Front. Microbiol. 2019, 10, 1136. [CrossRef]

2. Manrique, P.; Bolduc, B.; Walk, S.T.; van der Oost, J.; de Vos, W.M.; Young, M.J. Healthy human gut phageome. Proc. Natl. Acad. Sci. USA 2016, 113, 10400-10405. [CrossRef]

3. Rinninella, E.; Raoul, P.; Cintoni, M.; Franceschi, F.; Miggiano, G.A.D.; Gasbarrini, A.; Mele, M.C. What is the healthy gut microbiota composition? A changing ecosystem across age, environment, diet, and diseases. Microorganisms 2019, 7, 14. [CrossRef]

4. Ley, R.E.; Peterson, D.A.; Gordon, J.I. Ecological and evolutionary forces shaping microbial diversity in the human intestine. Cell 2006, 124, 837-848. [CrossRef]

5. The Human Microbiome Project | Nature. Available online: https://www.nature.com/articles/nature06244 (accessed on 21 January 2020).

6. Dieterich, W.; Schink, M.; Zopf, Y. Microbiota in the gastrointestinal tract. Med. Sci. (Basel) 2018, 6, 116. [CrossRef]

7. Evans, J.M.; Morris, L.S.; Marchesi, J.R. The gut microbiome: The role of a virtual organ in the endocrinology of the host. J. Endocrinol. 2013, 218, R37-R47. [CrossRef] [PubMed]

8. Oliphant, K.; Allen-Vercoe, E. Macronutrient metabolism by the human gut microbiome: Major fermentation by-products and their impact on host health. Microbiome 2019, 7, 91. [CrossRef] [PubMed]

9. Jasirwan, C.O.M.; Lesmana, C.R.A.; Hasan, I.; Sulaiman, A.S.; Gani, R.A. The role of gut microbiota in non-alcoholic fatty liver disease: Pathways of mechanisms. Biosci. Microbiota Food Health 2019, 38, 81-88. [CrossRef] [PubMed]

10. Sommer, F.; Bäckhed, F. The gut microbiota-Masters of host development and physiology. Nat. Rev. Microbiol. 2013, 11, 227-238. [CrossRef]

11. Sekirov, I.; Russell, S.L.; Antunes, L.C.M.; Finlay, B.B. Gut microbiota in health and disease. Physiol. Rev. 2010, 90, 859-904. [CrossRef]

12. Valles-Colomer, M.; Falony, G.; Darzi, Y.; Tigchelaar, E.F.; Wang, J.; Tito, R.Y.; Schiweck, C.; Kurilshikov, A.; Joossens, M.; Wijmenga, C.; et al. The neuroactive potential of the human gut microbiota in quality of life and depression. Nat. Microbiol. 2019, 4, 623-632. [CrossRef] [PubMed]

13. Dominguez-Bello, M.G.; Blaser, M.J.; Ley, R.E.; Knight, R. Development of the human gastrointestinal microbiota and insights from high-throughput sequencing. Gastroenterology 2011, 140, 1713-1719. [CrossRef] [PubMed]

14. Kim, Y.S.; Unno, T.; Kim, B.Y.; Park, M.S. Sex differences in gut microbiota. World J. Mens Health 2020, 38, 48-60. [CrossRef] [PubMed]

15. Bokulich, N.A.; Chung, J.; Battaglia, T.; Henderson, N.; Jay, M.; Li, H.; D Lieber, A.; Wu, F.; Perez-Perez, G.I.; Chen, Y.; et al. Antibiotics, birth mode, and diet shape microbiome maturation during early life. Sci. Transl. Med. 2016, 8, 343ra82. [CrossRef]

16. Pérez-Cobas, A.E.; Artacho, A.; Knecht, H.; Ferrús, M.L.; Friedrichs, A.; Ott, S.J.; Moya, A.; Latorre, A.; Gosalbes, M.J. Differential effects of antibiotic therapy on the structure and function of human gut microbiota. PLOS ONE 2013, 8, e80201. [CrossRef]

17. Exercise Modifies the Gut Microbiota with Positive Health Effects. PubMed-NCBI. Available online: https://www.ncbi.nlm.nih.gov/pubmed/28357027 (accessed on 21 January 2020).

18. Lopez-Minguez, J.; Gómez-Abellán, P.; Garaulet, M. Timing of breakfast, lunch, and dinner. Effects on obesity and metabolic risk. Nutrients 2019, 11, 2624. [CrossRef]

19. Ni, Y.; Wu, L.; Jiang, J.; Yang, T.; Wang, Z.; Ma, L.; Zheng, L.; Yang, X.; Wu, Z.; Fu, Z. Late-night eating-induced physiological dysregulation and circadian misalignment are accompanied by microbial dysbiosis. Mol. Nutr. Food Res. 2019, 63, e1900867. [CrossRef]

20. Gentile, C.L.; Weir, T.L. The gut microbiota at the intersection of diet and human health. Science 2018, 362, 776-780. [CrossRef]

21. Dreyer, J.L.; Liebl, A.L. Early colonization of the gut microbiome and its relationship with obesity. Hum. Microbiome J. 2018, 10, 1-5. [CrossRef] 
22. Guaraldi, F.; Salvatori, G. Effect of breast and formula feeding on gut microbiota shaping in newborns. Front. Cell. Infect. Microbiol. 2012, 2, 94. [CrossRef]

23. Baumann-Dudenhoeffer, A.M.; D'Souza, A.W.; Tarr, P.I.; Warner, B.B.; Dantas, G. Infant diet and maternal gestational weight gain predict early metabolic maturation of gut microbiomes. Nat. Med. 2018, 24, 1822-1829. [CrossRef] [PubMed]

24. Laursen, M.F.; Bahl, M.I.; Michaelsen, K.F.; Licht, T.R. First foods and gut microbes. Front. Microbiol. 2017, 8, 356. [CrossRef] [PubMed]

25. Jost, T.; Lacroix, C.; Braegger, C.; Chassard, C. Impact of human milk bacteria and oligosaccharides on neonatal gut microbiota establishment and gut health. Nutr. Rev. 2015, 73, 426-437. [CrossRef] [PubMed]

26. Isolauri, E.; Rautava, S.; Salminen, S.; Collado, M.C. Early-life nutrition and microbiome development. Nestle Nutr. Inst. Workshop Ser. 2019, 90, 151-162.

27. Ho, N.T.; Li, F.; Lee-Sarwar, K.A.; Tun, H.M.; Brown, B.P.; Pannaraj, P.S.; Bender, J.M.; Azad, M.B.; Thompson, A.L.; Weiss, S.T.; et al. Meta-analysis of effects of exclusive breastfeeding on infant gut microbiota across populations. Nat. Commun. 2018, 9, 1-13. [CrossRef]

28. Castaner, O.; Goday, A.; Park, Y.-M.; Lee, S.-H.; Magkos, F.; Shiow, S.-A.T.E.; Schröder, H. The gut microbiome profile in obesity: A systematic review. Int. J. Endocrinol. 2018, 2018, 4095789. [CrossRef]

29. Cong, X.; Judge, M.; Xu, W.; Diallo, A.; Janton, S.; Brownell, E.A.; Maas, K.; Graf, J. Influence of infant feeding type on gut microbiome development in hospitalized preterm infants. Nurs. Res. 2017, 66, 123-133. [CrossRef]

30. The Association Between Breastfeeding and Childhood Obesity: A Meta-Analysis. PubMed-NCBI. Available online: https://www.ncbi.nlm.nih.gov/pubmed/25495402 (accessed on 21 January 2020).

31. Lemas, D.J.; Yee, S.; Cacho, N.; Miller, D.; Cardel, M.; Gurka, M.; Janicke, D.; Shenkman, E. Exploring the contribution of maternal antibiotics and breastfeeding to development of the infant microbiome and pediatric obesity. Semin. Fetal. Neonatal Med. 2016, 21, 406-409. [CrossRef]

32. Laursen, M.F.; Andersen, L.B.B.; Michaelsen, K.F.; Mølgaard, C.; Trolle, E.; Bahl, M.I.; Licht, T.R. Infant gut microbiota development is driven by transition to family foods independent of maternal obesity. Msphere 2016, 1, e00069-15. [CrossRef]

33. Matsuyama, M.; Morrison, M.; Cao, K.-A.L.; Pruilh, S.; Davies, P.S.W.; Wall, C.; Lovell, A.; Hill, R.J. Dietary intake influences gut microbiota development of healthy Australian children from the age of one to two years. Sci. Rep. 2019, 9, 1-11. [CrossRef]

34. Lundgren, S.N.; Madan, J.C.; Emond, J.A.; Morrison, H.G.; Christensen, B.C.; Karagas, M.R.; Hoen, A.G. Maternal diet during pregnancy is related with the infant stool microbiome in a delivery mode-dependent manner. Microbiome 2018, 6, 109. [CrossRef] [PubMed]

35. Chu, D.M.; Antony, K.M.; Ma, J.; Prince, A.L.; Showalter, L.; Moller, M.; Aagaard, K.M. The early infant gut microbiome varies in association with a maternal high-fat diet. Genome Med. 2016, 8, 77. [CrossRef] [PubMed]

36. David, L.A.; Maurice, C.F.; Carmody, R.N.; Gootenberg, D.B.; Button, J.E.; Wolfe, B.E.; Ling, A.V.; Devlin, A.S.; Varma, Y.; Fischbach, M.A.; et al. Diet rapidly and reproducibly alters the human gut microbiome. Nature 2014, 505, 559-563. [CrossRef] [PubMed]

37. Nicolucci, A.C.; Hume, M.P.; Martínez, I.; Mayengbam, S.; Walter, J.; Reimer, R.A. Prebiotics reduce body fat and alter intestinal microbiota in children who are overweight or with obesity. Gastroenterology 2017, 153, 711-722. [CrossRef]

38. Lamuel-Raventos, R.M.; Onge, M.-P. Prebiotic nut compounds and human microbiota. Crit. Rev. Food Sci. Nutr. 2017, 57, 3154-3163. [CrossRef]

39. So, D.; Whelan, K.; Rossi, M.; Morrison, M.; Holtmann, G.; Kelly, J.T.; Shanahan, E.R.; Staudacher, H.M.; Campbell, K.L. Dietary fiber intervention on gut microbiota composition in healthy adults: A systematic review and meta-analysis. Am. J. Clin. Nutr. 2018, 107, 965-983. [CrossRef]

40. Fehlbaum, S.; Prudence, K.; Kieboom, J.; Heerikhuisen, M.; van den Broek, T.; Schuren, F.H.J.; Steinert, R.E.; Raederstorff, D. In Vitro fermentation of selected prebiotics and their effects on the composition and activity of the adult gut microbiota. Int. J. Mol. Sci. 2018, 19, 3097. [CrossRef]

41. Do, M.H.; Lee, E.; Oh, M.-J.; Kim, Y.; Park, H.-Y. High-glucose or-fructose diet cause changes of the gut microbiota and metabolic disorders in mice without body weight change. Nutrients 2018, 10, 761. [CrossRef] 
42. Sen, T.; Cawthon, C.R.; Ihde, B.T.; Hajnal, A.; DiLorenzo, P.M.; de La Serre, C.B.; Czaja, K. Diet-driven microbiota dysbiosis is associated with vagal remodeling and obesity. Physiol. Behav. 2017, 173, 305-317. [CrossRef]

43. Whelan, K.; Judd, P.A.; Preedy, V.R.; Simmering, R.; Jann, A.; Taylor, M.A. Fructooligosaccharides and fiber partially prevent the alterations in fecal microbiota and short-chain fatty acid concentrations caused by standard enteral formula in healthy humans. J. Nutr. 2005, 135, 1896-1902. [CrossRef]

44. Martínez, I.; Kim, J.; Duffy, P.R.; Schlegel, V.L.; Walter, J. Resistant starches types 2 and 4 have differential effects on the composition of the fecal microbiota in human subjects. PLoS ONE 2010, 5, e15046. [CrossRef] [PubMed]

45. Davis, L.M.G.; Martínez, I.; Walter, J.; Goin, C.; Hutkins, R.W. Barcoded pyrosequencing reveals that consumption of galactooligosaccharides results in a highly specific bifidogenic response in humans. PLOS ONE 2011, 6, e25200. [CrossRef] [PubMed]

46. Walker, A.W.; Ince, J.; Duncan, S.H.; Webster, L.M.; Holtrop, G.; Ze, X.; Brown, D.; Stares, M.D.; Scott, P.; Bergerat, A.; et al. Dominant and diet-responsive groups of bacteria within the human colonic microbiota. ISME J. 2011, 5, 220-230. [CrossRef] [PubMed]

47. Francavilla, R.; Calasso, M.; Calace, L.; Siragusa, S.; Ndagijimana, M.; Vernocchi, P.; Brunetti, L.; Mancino, G.; Tedeschi, G.; Guerzoni, E.; et al. Effect of lactose on gut microbiota and metabolome of infants with cow's milk allergy. Pediatr. Allergy Immunol. 2012, 23, 420-427. [CrossRef] [PubMed]

48. Hald, S.; Schioldan, A.G.; Moore, M.E.; Dige, A.; Lærke, H.N.; Agnholt, J.; Bach Knudsen, K.E.; Hermansen, K.; Marco, M.L.; Gregersen, S.; et al. Effects of arabinoxylan and resistant starch on intestinal microbiota and short-chain fatty acids in subjects with metabolic syndrome: A randomised crossover study. PLoS ONE 2016, 11, e0159223. [CrossRef] [PubMed]

49. Mardinoglu, A.; Wu, H.; Bjornson, E.; Zhang, C.; Hakkarainen, A.; Räsänen, S.M.; Lee, S.; Mancina, R.M.; Bergentall, M.; Pietiläinen, K.H.; et al. An integrated understanding of the rapid metabolic benefits of a carbohydrate-restricted diet on hepatic steatosis in humans. Cell Metab. 2018, 27, 559-571.e5. [CrossRef]

50. Jones, R.B.; Alderete, T.L.; Kim, J.S.; Millstein, J.; Gilliland, F.D.; Goran, M.I. High intake of dietary fructose in overweight/obese teenagers associated with depletion of Eubacterium and Streptococcus in gut microbiome. Gut Microbes 2019, 10, 712-719. [CrossRef]

51. Mills, S.; Stanton, C.; Lane, J.A.; Smith, G.J.; Ross, R.P. Precision nutrition and the microbiome, part I: Current state of the science. Nutrients 2019, 11,923. [CrossRef]

52. Parada Venegas, D.; De la Fuente, M.K.; Landskron, G.; González, M.J.; Quera, R.; Dijkstra, G.; Harmsen, H.J.M.; Faber, K.N.; Hermoso, M.A. Short chain fatty acids (SCFAs)-mediated gut epithelial and immune regulation and its relevance for inflammatory bowel diseases. Front. Immunol. 2019, 10, 1486. [CrossRef]

53. Zhang, L.S.; Davies, S.S. Microbial metabolism of dietary components to bioactive metabolites: Opportunities for new therapeutic interventions. Genome Med. 2016, 8, 46. [CrossRef]

54. Scott, K.P.; Duncan, S.H.; Flint, H.J. Dietary fibre and the gut microbiota. Nutr. Bull. 2008, 33, $201-211$. [CrossRef]

55. Desai, M.S.; Seekatz, A.M.; Koropatkin, N.M.; Kamada, N.; Hickey, C.A.; Wolter, M.; Pudlo, N.A.; Kitamoto, S.; Terrapon, N.; Muller, A.; et al. A dietary fiber-deprived gut microbiota degrades the colonic mucus barrier and enhances pathogen susceptibility. Cell 2016, 167, 1339-1353.e21. [CrossRef] [PubMed]

56. Diether, N.E.; Willing, B.P. Microbial fermentation of dietary protein: An important factor in diet-microbe-host interaction. Microorganisms 2019, 7, 19. [CrossRef] [PubMed]

57. Hentges, D.J.; Maier, B.R.; Burton, G.C.; Flynn, M.A.; Tsutakawa, R.K. Effect of a high-beef diet on the fecal bacterial flora of humans. Cancer Res. 1977, 37, 568-571.

58. Madsen, L.; Myrmel, L.S.; Fjære, E.; Liaset, B.; Kristiansen, K. Links between dietary protein sources, the gut microbiota, and obesity. Front. Physiol. 2017, 8, 1047. [CrossRef]

59. Tomova, A.; Bukovsky, I.; Rembert, E.; Yonas, W.; Alwarith, J.; Barnard, N.D.; Kahleova, H. The effects of vegetarian and vegan diets on gut microbiota. Front. Nutr. 2019, 6, 47. [CrossRef]

60. Cotillard, A.; Kennedy, S.P.; Kong, L.C.; Prifti, E.; Pons, N.; Le Chatelier, E.; Almeida, M.; Quinquis, B.; Levenez, F.; Galleron, N.; et al. Dietary intervention impact on gut microbial gene richness. Nature 2013, 500, 585-588. [CrossRef] 
61. Filippo, C.D.; Cavalieri, D.; Paola, M.D.; Ramazzotti, M.; Poullet, J.B.; Massart, S.; Collini, S.; Pieraccini, G.; Lionetti, P. Impact of diet in shaping gut microbiota revealed by a comparative study in children from Europe and rural Africa. PNAS 2010, 107, 14691-14696. [CrossRef]

62. Russell, W.R.; Gratz, S.W.; Duncan, S.H.; Holtrop, G.; Ince, J.; Scobbie, L.; Duncan, G.; Johnstone, A.M.; Lobley, G.E.; Wallace, R.J.; et al. High-protein, reduced-carbohydrate weight-loss diets promote metabolite profiles likely to be detrimental to colonic health. Am. J. Clin. Nutr. 2011, 93, 1062-1072. [CrossRef]

63. Holmes, E.; Li, J.V.; Athanasiou, T.; Ashrafian, H.; Nicholson, J.K. Understanding the role of gut microbiome-host metabolic signal disruption in health and disease. Trends Microbiol. 2011, 19, 349-359. [CrossRef]

64. Meddah, A.T.; Yazourh, A.; Desmet, I.; Risbourg, B.; Verstraete, W.; Romond, M.B. The regulatory effects of whey retentate from bifidobacteria fermented milk on the microbiota of the simulator of the human intestinal microbial ecosystem (SHIME). J. Appl. Microbiol. 2001, 91, 1110-1117. [CrossRef] [PubMed]

65. Świątecka, D.; Dominika, S.; Narbad, A.; Arjan, N.; Ridgway, K.P.; Karyn, R.P.; Kostyra, H.; Henryk, K. The study on the impact of glycated pea proteins on human intestinal bacteria. Int. J. Food Microbiol. 2011, 145, 267-272. [PubMed]

66. Zhao, F.; Huang, Z.; Zhou, G.; Li, H.; Xu, X.; Li, C. Dietary proteins rapidly altered the microbial composition in rat caecum. Curr. Microbiol. 2017, 74, 1447-1452. [CrossRef]

67. Butteiger, D.N.; Hibberd, A.A.; McGraw, N.J.; Napawan, N.; Hall-Porter, J.M.; Krul, E.S. Soy protein compared with milk protein in a western diet increases gut microbial diversity and reduces serum lipids in golden syrian hamsters. J. Nutr. 2016, 146, 697-705. [CrossRef] [PubMed]

68. Zhou, X.-L.; Yan, B.-B.; Xiao, Y.; Zhou, Y.-M.; Liu, T.-Y. Tartary buckwheat protein prevented dyslipidemia in high-fat diet-fed mice associated with gut microbiota changes. Food Chem. Toxicol. 2018, 119, $296-301$. [CrossRef] [PubMed]

69. Mori, T.; Kondo, H.; Hase, T.; Tokimitsu, I.; Murase, T. Dietary fish oil upregulates intestinal lipid metabolism and reduces body weight gain in C57BL/6J mice. J. Nutr. 2007, 137, 2629-2634. [CrossRef]

70. Fava, F.; Gitau, R.; Griffin, B.A.; Gibson, G.R.; Tuohy, K.M.; Lovegrove, J.A. The type and quantity of dietary fat and carbohydrate alter faecal microbiome and short-chain fatty acid excretion in a metabolic syndrome “at-risk" population. Int. J. Obes. (Lond.) 2013, 37, 216-223. [CrossRef]

71. Carmody, R.N.; Gerber, G.K.; Luevano, J.M.; Gatti, D.M.; Somes, L.; Svenson, K.L.; Turnbaugh, P.J. Diet dominates host genotype in shaping the murine gut microbiota. Cell Host Microbe 2015, 17, 72-84. [CrossRef]

72. de Velasco, P.; Ferreira, A.; Crovesy, L.; Marine, T.; do Carmo, M.D.G.T. Fatty acids, gut microbiota, and the genesis of obesity. In Biochemistry and Health Benefits of Fatty Acids; IntechOpen: London, UK, 2018.

73. Cutting Edge: Toll-like Receptor 4 (TLR4)-Deficient Mice are Hyporesponsive to Lipopolysaccharide: Evidence for TLR4 as the Lps Gene Product. PubMed-NCBI. Available online: https://www.ncbi.nlm.nih. gov/pubmed/10201887 (accessed on 29 January 2020).

74. Lam, Y.Y.; Ha, C.W.Y.; Hoffmann, J.M.A.; Oscarsson, J.; Dinudom, A.; Mather, T.J.; Cook, D.I.; Hunt, N.H.; Caterson, I.D.; Holmes, A.J.; et al. Effects of dietary fat profile on gut permeability and microbiota and their relationships with metabolic changes in mice. Obesity (Silver Spring) 2015, 23, 1429-1439. [CrossRef]

75. Caesar, R.; Tremaroli, V.; Kovatcheva-Datchary, P.; Cani, P.D.; Bäckhed, F. Crosstalk between gut microbiota and dietary lipids aggravates WAT inflammation through TLR signaling. Cell Metab. 2015, 22, 658-668. [CrossRef]

76. Bamberger, C.; Rossmeier, A.; Lechner, K.; Wu, L.; Waldmann, E.; Fischer, S.; Stark, R.G.; Altenhofer, J.; Henze, K.; Parhofer, K.G. A walnut-enriched diet affects gut microbiome in healthy caucasian subjects: A randomized, controlled trial. Nutrients 2018, 10, 244. [CrossRef] [PubMed]

77. Guetterman, H.M.; Swanson, K.S.; Novotny, J.A.; Baer, D.J.; Holscher, H.D. Walnut consumption influences the human gut microbiome. FASEB J. 2016, 30, 406-2.

78. Tindall, A.; McLimans, C.; Petersen, K.; Kris-Etherton, P.; Lamendella, R. Walnuts and vegetable oils differentially affect the gut microbiome and associations with cardiovascular risk factors (OR29-06-19). Curr. Dev. Nutr. 2019, 3, nzz031-OR29. [CrossRef]

79. Devkota, S.; Wang, Y.; Musch, M.W.; Leone, V.; Fehlner-Peach, H.; Nadimpalli, A.; Antonopoulos, D.A.; Jabri, B.; Chang, E.B. Dietary-fat-induced taurocholic acid promotes pathobiont expansion and colitis in Il10-/-mice. Nature 2012, 487, 104-108. [CrossRef] 
80. Wolters, M.; Ahrens, J.; Romaní-Pérez, M.; Watkins, C.; Sanz, Y.; Benítez-Páez, A.; Stanton, C.; Günther, K. Dietary fat, the gut microbiota, and metabolic health-A systematic review conducted within the My New Gut project. Clin. Nutr. 2019, 38, 2504-2520. [CrossRef]

81. Kumar Singh, A.; Cabral, C.; Kumar, R.; Ganguly, R.; Kumar Rana, H.; Gupta, A.; Rosaria Lauro, M.; Carbone, C.; Reis, F.; Pandey, A.K. Beneficial effects of dietary polyphenols on gut microbiota and strategies to improve delivery efficiency. Nutrients 2019, 11, 2216. [CrossRef]

82. The Food and Agriculture Organization of the United Nations; The World Health Organization. Report of a joint fao/who working group on drafting guidelines for the evaluation of probiotics in food. In Guidelines for Evaluation of Probiotics in Food; FAO/WHO: London, ON, Canada, 2002.

83. Santos-Marcos, J.A.; Perez-Jimenez, F.; Camargo, A. The role of diet and intestinal microbiota in the development of metabolic syndrome. J. Nutr. Biochem. 2019, 70, 1-27. [CrossRef]

84. Azad, M.A.K.; Sarker, M.; Li, T.; Yin, J. Probiotic species in the modulation of gut microbiota: An overview. Biomed Res. Int. 2018, 2018, 1-8. [CrossRef]

85. Jaeggi, T.; Kortman, G.A.M.; Moretti, D.; Chassard, C.; Holding, P.; Dostal, A.; Boekhorst, J.; Timmerman, H.M.; Swinkels, D.W.; Tjalsma, H.; et al. Iron fortification adversely affects the gut microbiome, increases pathogen abundance and induces intestinal inflammation in Kenyan infants. Gut 2015, 64, 731-742. [CrossRef]

86. Zimmermann, M.B.; Chassard, C.; Rohner, F.; N'goran, E.K.; Nindjin, C.; Dostal, A.; Utzinger, J.; Ghattas, H.; Lacroix, C.; Hurrell, R.F. The effects of iron fortification on the gut microbiota in African children: A randomized controlled trial in Cote d'Ivoire. Am. J. Clin. Nutr. 2010, 92, 1406-1415. [CrossRef]

87. Mahalhal, A.; Williams, J.M.; Johnson, S.; Ellaby, N.; Duckworth, C.A.; Burkitt, M.D.; Liu, X.; Hold, G.L.; Campbell, B.J.; Pritchard, D.M.; et al. Oral iron exacerbates colitis and influences the intestinal microbiome. PLoS ONE 2018, 13, e0202460. [CrossRef] [PubMed]

88. Waterhouse, M.; Hope, B.; Krause, L.; Morrison, M.; Protani, M.M.; Zakrzewski, M.; Neale, R.E. Vitamin D and the gut microbiome: A systematic review of In Vivo studies. Eur. J. Nutr. 2019, 58, 2895-2910. [CrossRef] [PubMed]

89. Naderpoor, N.; Mousa, A.; Fernanda Gomez Arango, L.; Barrett, H.L.; Dekker Nitert, M.; de Courten, B. Effect of vitamin d supplementation on faecal microbiota: A randomised clinical trial. Nutrients 2019, 11, 2888. [CrossRef] [PubMed]

90. Charoenngam, N.; Shirvani, A.; Kalajian, T.A.; Song, A.; Holick, M.F. The effect of various doses of oral vitamin D3 supplementation on gut microbiota in healthy adults: A randomized, double-blinded, dose-response study. Anticancer Res. 2020, 40, 551-556. [CrossRef]

91. Wang, G.; Liu, Q.; Guo, L.; Zeng, H.; Ding, C.; Zhang, W.; Xu, D.; Wang, X.; Qiu, J.; Dong, Q.; et al. Gut microbiota and relevant metabolites analysis in alcohol dependent mice. Front. Microbiol. 2018, 9, 1874. [CrossRef]

92. Litwinowicz, K.; Choroszy, M.; Waszczuk, E. Changes in the composition of the human intestinal microbiome in alcohol use disorder: A systematic review. Am. J. Drug Alcohol Abuse 2020, 46, 4-12. [CrossRef]

93. Addolorato, G.; Ponziani, F.R.; Dionisi, T.; Mosoni, C.; Vassallo, G.A.; Sestito, L.; Petito, V.; Picca, A.; Marzetti, E.; Tarli, C.; et al. Gut microbiota compositional and functional fingerprint in patients with alcohol use disorder and alcohol associated liver disease. Liver Int. 2020, 40, 878-888. [CrossRef]

94. Vitaglione, P.; Mazzone, G.; Lembo, V.; D’Argenio, G.; Rossi, A.; Guido, M.; Savoia, M.; Salomone, F.; Mennella, I.; De Filippis, F.; et al. Coffee prevents fatty liver disease induced by a high-fat diet by modulating pathways of the gut-liver axis. J. Nutr. Sci. 2019, 8, e15. [CrossRef]

95. Jaquet, M.; Rochat, I.; Moulin, J.; Cavin, C.; Bibiloni, R. Impact of coffee consumption on the gut microbiota: A human volunteer study. Int. J. Food Microbiol. 2009, 130, 117-121. [CrossRef]

96. Seo, D.-B.; Jeong, H.W.; Kim, Y.-J.; Kim, S.; Kim, J.; Lee, J.H.; Joo, K.; Choi, J.K.; Shin, S.S.; Lee, S.-J. Fermented green tea extract exhibits hypolipidaemic effects through the inhibition of pancreatic lipase and promotion of energy expenditure. Br. J. Nutr. 2017, 117, 177-186. [CrossRef]

97. Liu, J.; Hao, W.; He, Z.; Kwek, E.; Zhao, Y.; Zhu, H.; Liang, N.; Ma, K.Y.; Lei, L.; He, W.-S.; et al. Beneficial effects of tea water extracts on the body weight and gut microbiota in C57BL/6J mice fed with a high-fat diet. Food Funct. 2019, 10, 2847-2860. [CrossRef] [PubMed]

98. Yuan, X.; Long, Y.; Ji, Z.; Gao, J.; Fu, T.; Yan, M.; Zhang, L.; Su, H.; Zhang, W.; Wen, X.; et al. Green tea liquid consumption alters the human intestinal and oral microbiome. Mol. Nutr. Food Res. 2018, 62, 1800178. [CrossRef] [PubMed] 
99. Huang, F.; Zheng, X.; Ma, X.; Jiang, R.; Zhou, W.; Zhou, S.; Zhang, Y.; Lei, S.; Wang, S.; Kuang, J.; et al. Theabrownin from Pu-erh tea attenuates hypercholesterolemia via modulation of gut microbiota and bile acid metabolism. Nat. Commun. 2019, 10,1-17. [CrossRef] [PubMed]

100. Bier, A.; Braun, T.; Khasbab, R.; Di Segni, A.; Grossman, E.; Haberman, Y.; Leibowitz, A. A high salt diet modulates the gut microbiota and short chain fatty acids production in a salt-sensitive hypertension rat model. Nutrients 2018, 10, 1154. [CrossRef]

101. Miranda, P.M.; De Palma, G.; Serkis, V.; Lu, J.; Louis-Auguste, M.P.; McCarville, J.L.; Verdu, E.F.; Collins, S.M.; Bercik, P. High salt diet exacerbates colitis in mice by decreasing Lactobacillus levels and butyrate production. Microbiome 2018, 6, 57. [CrossRef]

102. Wilck, N.; Matus, M.G.; Kearney, S.M.; Olesen, S.W.; Forslund, K.; Bartolomaeus, H.; Haase, S.; Mähler, A.; Balogh, A.; Markó, L.; et al. Salt-responsive gut commensal modulates TH17 axis and disease. Nature 2017, 551, 585-589. [CrossRef]

103. Fiber-Utilizing Capacity Varies in Prevotella-Versus Bacteroides-Dominated Gut Microbiota. Available online: https://www.ncbi.nlm.nih.gov/pmc/articles/PMC5453967/ (accessed on 28 January 2020).

104. De Filippo, C.; Di Paola, M.; Ramazzotti, M.; Albanese, D.; Pieraccini, G.; Banci, E.; Miglietta, F.; Cavalieri, D.; Lionetti, P. Diet, environments, and gut microbiota. A preliminary investigation in children living in rural and urban burkina faso and Italy. Front. Microbiol. 2017, 8, 1979. [CrossRef]

105. Schnorr, S.L.; Candela, M.; Rampelli, S.; Centanni, M.; Consolandi, C.; Basaglia, G.; Turroni, S.; Biagi, E.; Peano, C.; Severgnini, M.; et al. Gut microbiome of the Hadza hunter-gatherers. Nat. Commun. 2014, 5, 3654. [CrossRef]

106. Sonnenburg, E.D.; Smits, S.A.; Tikhonov, M.; Higginbottom, S.K.; Wingreen, N.S.; Sonnenburg, J.L. Diet-induced extinction in the gut microbiota compounds over generations. Nature 2016, 529, $212-215$. [CrossRef]

107. Klimenko, N.S.; Tyakht, A.V.; Popenko, A.S.; Vasiliev, A.S.; Altukhov, I.A.; Ischenko, D.S.; Shashkova, T.I.; Efimova, D.A.; Nikogosov, D.A.; Osipenko, D.A.; et al. Microbiome responses to an uncontrolled short-term diet intervention in the frame of the citizen science project. Nutrients 2018, 10, 576. [CrossRef]

108. Ruengsomwong, S.; La-ongkham, O.; Jiang, J.; Wannissorn, B.; Nakayama, J.; Nitisinprasert, S. Microbial community of healthy thai vegetarians and non-vegetarians, their core gut microbiota, and pathogen risk. J. Microbiol. Biotechnol. 2016, 26, 1723-1735. [CrossRef] [PubMed]

109. Jain, A.; Li, X.H.; Chen, W.N. Similarities and differences in gut microbiome composition correlate with dietary patterns of Indian and Chinese adults. AMB Express 2018, 8, 104. [CrossRef] [PubMed]

110. Matijašić, B.B.; Obermajer, T.; Lipoglavšek, L.; Grabnar, I.; Avguštin, G.; Rogelj, I. Association of dietary type with fecal microbiota in vegetarians and omnivores in Slovenia. Eur. J. Nutr. 2014, 53, 1051-1064. [CrossRef]

111. Glick-Bauer, M.; Yeh, M.-C. The health advantage of a vegan diet: Exploring the gut microbiota connection. Nutrients 2014, 6, 4822-4838. [CrossRef]

112. Cao, H.; Xu, M.; Dong, W.; Deng, B.; Wang, S.; Zhang, Y.; Wang, S.; Luo, S.; Wang, W.; Qi, Y.; et al. Secondary bile acid-induced dysbiosis promotes intestinal carcinogenesis. Int. J. Cancer 2017, 140, 2545-2556. [CrossRef]

113. Martínez-González, M.A.; Gea, A.; Ruiz-Canela, M. The mediterranean diet and cardiovascular health. Circ. Res. 2019, 124, 779-798. [CrossRef]

114. Castro-Barquero, S.; Lamuela-Raventós, R.M.; Doménech, M.; Estruch, R. Relationship between mediterranean dietary polyphenol intake and obesity. Nutrients 2018, 10, 1523. [CrossRef] [PubMed]

115. Mitsou, E.K.; Kakali, A.; Antonopoulou, S.; Mountzouris, K.C.; Yannakoulia, M.; Panagiotakos, D.B.; Kyriacou, A. Adherence to the Mediterranean diet is associated with the gut microbiota pattern and gastrointestinal characteristics in an adult population. Br. J. Nutr. 2017, 117, 1645-1655. [CrossRef]

116. Filippis, F.D.; Pellegrini, N.; Vannini, L.; Jeffery, I.B.; Storia, A.L.; Laghi, L.; Serrazanetti, D.I.; Cagno, R.D.; Ferrocino, I.; Lazzi, C.; et al. High-level adherence to a Mediterranean diet beneficially impacts the gut microbiota and associated metabolome. Gut 2016, 65, 1812-1821. [CrossRef]

117. Haro, C.; García-Carpintero, S.; Rangel-Zúñiga, O.A.; Alcalá-Díaz, J.F.; Landa, B.B.; Clemente, J.C.; Pérez-Martínez, P.; López-Miranda, J.; Pérez-Jiménez, F.; Camargo, A. Consumption of two healthy dietary patterns restored microbiota dysbiosis in obese patients with metabolic dysfunction. Mol. Nutr. Food Res. 2017, 61, 1700300. [CrossRef]

118. Gutiérrez-Díaz, I.; Fernández-Navarro, T.; Sánchez, B.; Margolles, A.; González, S. Mediterranean diet and faecal microbiota: A transversal study. Food Funct. 2016, 7, 2347-2356. [CrossRef] [PubMed] 
119. Schroeder, B.O.; Birchenough, G.M.H.; Ståhlman, M.; Arike, L.; Johansson, M.E.V.; Hansson, G.C.; Bäckhed, F. Bifidobacteria or fiber protects against diet-induced microbiota-mediated colonic mucus deterioration. Cell Host Microbe 2018, 23, 27-40.e7. [CrossRef] [PubMed]

120. Laudisi, F.; Stolfi, C.; Monteleone, G. Impact of food additives on gut homeostasis. Nutrients 2019, 11, 2334. [CrossRef] [PubMed]

121. Partridge, D.; Lloyd, K.A.; Rhodes, J.M.; Walker, A.W.; Johnstone, A.M.; Campbell, B.J. Food additives: Assessing the impact of exposure to permitted emulsifiers on bowel and metabolic health-Introducing the FADiets study. Nutr. Bull. 2019, 44, 329-349. [CrossRef]

122. Martínez Leo, E.E.; Segura Campos, M.R. Effect of ultra-processed diet on gut microbiota and thus its role in neurodegenerative diseases. Nutrition 2019, 71, 110609. [CrossRef]

123. Viennois, E.; Chassaing, B. First victim, later aggressor: How the intestinal microbiota drives the pro-inflammatory effects of dietary emulsifiers? Gut Microbes 2018, 9, 289-291. [CrossRef]

124. Suez, J.; Korem, T.; Zeevi, D.; Zilberman-Schapira, G.; Thaiss, C.A.; Maza, O.; Israeli, D.; Zmora, N.; Gilad, S.; Weinberger, A.; et al. Artificial sweeteners induce glucose intolerance by altering the gut microbiota. Nature 2014, 514, 181-186. [CrossRef]

125. Chassaing, B.; Van de Wiele, T.; De Bodt, J.; Marzorati, M.; Gewirtz, A.T. Dietary emulsifiers directly alter human microbiota composition and gene expression ex vivo potentiating intestinal inflammation. Gut 2017, 66, 1414-1427. [CrossRef]

126. Bian, X.; Chi, L.; Gao, B.; Tu, P.; Ru, H.; Lu, K. Gut microbiome response to sucralose and its potential role in inducing liver inflammation in mice. Front. Physiol. 2017, 8, 487. [CrossRef]

127. Chi, L.; Bian, X.; Gao, B.; Tu, P.; Lai, Y.; Ru, H.; Lu, K. Effects of the artificial sweetener neotame on the gut microbiome and fecal metabolites in mice. Molecules 2018, 23, 367. [CrossRef]

128. Olivier-Van Stichelen, S.; Rother, K.I.; Hanover, J.A. Maternal exposure to non-nutritive sweeteners impacts progeny's metabolism and microbiome. Front. Microbiol. 2019, 10, 1360. [CrossRef] [PubMed]

129. De Palma, G.; Nadal, I.; Collado, M.C.; Sanz, Y. Effects of a gluten-free diet on gut microbiota and immune function in healthy adult human subjects. Br. J. Nutr. 2009, 102, 1154-1160. [CrossRef] [PubMed]

130. Golfetto, L.; Senna, F.D.D.; Hermes, J.; Beserra, B.T.S.; França, F.D.S.; Martinello, F. Lower bifidobacteria counts in adult patients with celiac disease on a gluten-free diet. Arq. Gastroenterol. 2014, 51, 139-143. [CrossRef] [PubMed]

131. Sanz, Y. Effects of a gluten-free diet on gut microbiota and immune function in healthy adult humans. Gut Microbes 2010, 1, 135-137. [CrossRef]

132. Bonder, M.J.; Tigchelaar, E.F.; Cai, X.; Trynka, G.; Cenit, M.C.; Hrdlickova, B.; Zhong, H.; Vatanen, T.; Gevers, D.; Wijmenga, C.; et al. The influence of a short-term gluten-free diet on the human gut microbiome. Genome Med. 2016, 8, 45. [CrossRef]

133. Fan, Y.; Wang, H.; Liu, X.; Zhang, J.; Liu, G. Crosstalk between the ketogenic diet and epilepsy: From the perspective of gut microbiota. Mediat. Inflamm. 2019, 2019, 8373060. [CrossRef]

134. Paoli, A.; Mancin, L.; Bianco, A.; Thomas, E.; Mota, J.F.; Piccini, F. Ketogenic diet and microbiota: Friends or enemies? Genes (Basel) 2019, 10, 534. [CrossRef]

135. Genoni, A.; Christophersen, C.T.; Lo, J.; Coghlan, M.; Boyce, M.C.; Bird, A.R.; Lyons-Wall, P.; Devine, A. Long-term Paleolithic diet is associated with lower resistant starch intake, different gut microbiota composition and increased serum TMAO concentrations. Eur. J. Nutr. 2019, 1-14. [CrossRef]

136. Barone, M.; Turroni, S.; Rampelli, S.; Soverini, M.; D’Amico, F.; Biagi, E.; Brigidi, P.; Troiani, E.; Candela, M. Gut microbiome response to a modern Paleolithic diet in a Western lifestyle context. PLoS ONE 2019, 14, e0220619. [CrossRef]

137. Li, G.; Xie, C.; Lu, S.; Nichols, R.G.; Tian, Y.; Li, L.; Patel, D.; Ma, Y.; Brocker, C.N.; Yan, T.; et al. Intermittent fasting promotes white adipose browning and decreases obesity by shaping the gut microbiota. Cell Metab. 2017, 26, 672-685.e4. [CrossRef]

138. Özkul, C.; Yalınay, M.; Karakan, T. Islamic fasting leads to an increased abundance of Akkermansia muciniphila and Bacteroides fragilis group: A preliminary study on intermittent fasting. Turk. J. Gastroenterol. 2019, 30, 1030-1035. [CrossRef] [PubMed]

139. Hansen, L.B.S.; Roager, H.M.; Søndertoft, N.B.; Gøbel, R.J.; Kristensen, M.; Vallès-Colomer, M.; Vieira-Silva, S.; Ibrügger, S.; Lind, M.V.; Mærkedahl, R.B.; et al. A low-gluten diet induces changes in the intestinal microbiome of healthy Danish adults. Nat. Commun. 2018, 9, 1-13. [CrossRef] [PubMed] 
140. Xie, G.; Zhou, Q.; Qiu, C.-Z.; Dai, W.-K.; Wang, H.-P.; Li, Y.-H.; Liao, J.-X.; Lu, X.-G.; Lin, S.-F.; Ye, J.-H.; et al. Ketogenic diet poses a significant effect on imbalanced gut microbiota in infants with refractory epilepsy. World J. Gastroenterol. 2017, 23, 6164-6171. [CrossRef] [PubMed]

141. Spinelli, E.; Blackford, R. Gut microbiota, the ketogenic diet and epilepsy. Pediatr. Neurol. Briefs 2018, 32, 10. [CrossRef]

142. Turnbaugh, P.J.; Ley, R.E.; Mahowald, M.A.; Magrini, V.; Mardis, E.R.; Gordon, J.I. An obesity-associated gut microbiome with increased capacity for energy harvest. Nature 2006, 444, 1027-1031. [CrossRef]

143. Bäckhed, F.; Ding, H.; Wang, T.; Hooper, L.V.; Koh, G.Y.; Nagy, A.; Semenkovich, C.F.; Gordon, J.I. The gut microbiota as an environmental factor that regulates fat storage. Proc. Natl. Acad. Sci. USA 2004, 101, 15718-15723. [CrossRef]

144. Rabot, S.; Membrez, M.; Bruneau, A.; Gérard, P.; Harach, T.; Moser, M.; Raymond, F.; Mansourian, R.; Chou, C.J. Germ-free C57BL/6J mice are resistant to high-fat-diet-induced insulin resistance and have altered cholesterol metabolism. FASEB J. 2010, 24, 4948-4959.

145. Riva, A.; Borgo, F.; Lassandro, C.; Verduci, E.; Morace, G.; Borghi, E.; Berry, D. Pediatric obesity is associated with an altered gut microbiota and discordant shifts in Firmicutes populations. Environ Microbiol 2017, 19, 95-105. [CrossRef]

146. Le Chatelier, E.; Nielsen, T.; Qin, J.; Prifti, E.; Hildebrand, F.; Falony, G.; Almeida, M.; Arumugam, M.; Batto, J.-M.; Kennedy, S.; et al. Richness of human gut microbiome correlates with metabolic markers. Nature 2013, 500, 541-546. [CrossRef]

147. Kim, K.N.; Yao, Y.; Ju, S.Y. Short chain fatty acids and fecal microbiota abundance in humans with obesity: A systematic review and meta-analysis. Nutrients 2019, 11, 2512. [CrossRef]

148. Goffredo, M.; Mass, K.; Parks, E.J.; Wagner, D.A.; McClure, E.A.; Graf, J.; Savoye, M.; Pierpont, B.; Cline, G.; Santoro, N. Role of gut microbiota and short chain fatty acids in modulating energy harvest and fat partitioning in youth. J. Clin. Endocrinol. Metab. 2016, 101, 4367-4376. [CrossRef] [PubMed]

149. Karlsson, F.H.; Tremaroli, V.; Nookaew, I.; Bergström, G.; Behre, C.J.; Fagerberg, B.; Nielsen, J.; Bäckhed, F. Gut metagenome in European women with normal, impaired and diabetic glucose control. Nature 2013, 498, 99-103. [CrossRef] [PubMed]

150. Larsen, N.; Vogensen, F.K.; van den Berg, F.W.J.; Nielsen, D.S.; Andreasen, A.S.; Pedersen, B.K.; Al-Soud, W.A.; Sørensen, S.J.; Hansen, L.H.; Jakobsen, M. Gut microbiota in human adults with type 2 diabetes differs from non-diabetic adults. PLoS ONE 2010, 5, e9085. [CrossRef] [PubMed]

151. A Metagenome-Wide Association Study of Gut Microbiota in Type 2 Diabetes. PubMed-NCBI. Available online: https://www.ncbi.nlm.nih.gov/pubmed/23023125?dopt=Abstract (accessed on 28 January 2020).

152. Wang, X.; Xu, X.; Xia, Y. Further analysis reveals new gut microbiome markers of type 2 diabetes mellitus. Antonie Van Leeuwenhoek 2017, 110, 445-453. [CrossRef]

153. Tilg, H.; Moschen, A.R. Microbiota and diabetes: An evolving relationship. Gut 2014, 63, $1513-1521$. [CrossRef]

154. Amar, J.; Serino, M.; Lange, C.; Chabo, C.; Iacovoni, J.; Mondot, S.; Lepage, P.; Klopp, C.; Mariette, J.; Bouchez, O.; et al. Involvement of tissue bacteria in the onset of diabetes in humans: Evidence for a concept. Diabetologia 2011, 54, 3055-3061. [CrossRef]

155. Cani, P.D.; Amar, J.; Iglesias, M.A.; Poggi, M.; Knauf, C.; Bastelica, D.; Neyrinck, A.M.; Fava, F.; Tuohy, K.M.; Chabo, C.; et al. Metabolic endotoxemia initiates obesity and insulin resistance. Diabetes 2007, 56, 1761-1772. [CrossRef]

156. Creely, S.J.; McTernan, P.G.; Kusminski, C.M.; Fisher, F.M.; Da Silva, N.F.; Khanolkar, M.; Evans, M.; Harte, A.L.; Kumar, S. Lipopolysaccharide activates an innate immune system response in human adipose tissue in obesity and type 2 diabetes. Am. J. Physiol. Endocrinol. Metab. 2007, 292, E740-E747. [CrossRef]

157. Nilsson, A.C.; Johansson-Boll, E.V.; Björck, I.M.E. Increased gut hormones and insulin sensitivity index following a 3-d intervention with a barley kernel-based product: A randomised cross-over study in healthy middle-aged subjects. Br. J. Nutr. 2015, 114, 899-907. [CrossRef]

158. Jellinger, P.S.; Handelsman, Y.; Rosenblit, P.D.; Bloomgarden, Z.T.; Fonseca, V.A.; Garber, A.J.; Grunberger, G.; Guerin, C.K.; Bell, D.S.H.; Mechanick, J.I.; et al. American association of clinical endocrinologists and american college of endocrinology guidelines for management of dyslipidemia and prevention of cardiovascular disease-executive summary complete appendix to guidelines. Endocr. Pract. 2017, 23, 479-497. [CrossRef] 
159. Emoto, T.; Yamashita, T.; Sasaki, N.; Hirota, Y.; Hayashi, T.; So, A.; Kasahara, K.; Yodoi, K.; Matsumoto, T.; Mizoguchi, T.; et al. Analysis of gut microbiota in coronary artery disease patients: A possible link between gut microbiota and coronary artery disease. J. Atheroscler. Thromb. 2016, 23, 908-921. [CrossRef] [PubMed]

160. Yoo, S.-R.; Kim, Y.-J.; Park, D.-Y.; Jung, U.-J.; Jeon, S.-M.; Ahn, Y.-T.; Huh, C.-S.; McGregor, R.; Choi, M.S. Probiotics L. plantarum and L. curvatus in combination alter hepatic lipid metabolism and suppress diet-induced obesity. Obesity (Silver Spring) 2013, 21, 2571-2578. [CrossRef] [PubMed]

161. An, H.M.; Park, S.Y.; Lee, D.K.; Kim, J.R.; Cha, M.K.; Lee, S.W.; Lim, H.T.; Kim, K.J.; Ha, N.J. Antiobesity and lipid-lowering effects of Bifidobacterium spp. in high fat diet-induced obese rats. Lipids Health Dis. 2011, 10, 116. [CrossRef] [PubMed]

162. Pappo, I.; Becovier, H.; Berry, E.M.; Freund, H.R. Polymyxin B reduces cecal flora, TNF production and hepatic steatosis during total parenteral nutrition in the rat. J. Surg. Res. 1991, 51, 106-112. [CrossRef]

163. Cani, P.D.; Delzenne, N.M. The gut microbiome as therapeutic target. Pharmacol. Ther. 2011, 130, $202-212$. [CrossRef]

164. Payne, A.N.; Chassard, C.; Zimmermann, M.; Müller, P.; Stinca, S.; Lacroix, C. The metabolic activity of gut microbiota in obese children is increased compared with normal-weight children and exhibits more exhaustive substrate utilization. Nutr. Diabetes 2011, 1, e12. [CrossRef]

165. Energy-Balance Studies Reveal Associations between Gut Microbes, Caloric Load, and Nutrient Absorption in Humans. PubMed-NCBI. Available online: https://www.ncbi.nlm.nih.gov/pubmed/21543530 (accessed on 23 January 2020).

166. Tilg, H.; Kaser, A. Gut microbiome, obesity, and metabolic dysfunction. J. Clin. Invest. 2011, 121, $2126-2132$. [CrossRef]

167. Bjursell, M.; Admyre, T.; Göransson, M.; Marley, A.E.; Smith, D.M.; Oscarsson, J.; Bohlooly-Y, M. Improved glucose control and reduced body fat mass in free fatty acid receptor 2-deficient mice fed a high-fat diet. Am. J. Physiol. Endocrinol. Metab. 2011, 300, E211-E220. [CrossRef]

168. Sun, L.; Ma, L.; Ma, Y.; Zhang, F.; Zhao, C.; Nie, Y. Insights into the role of gut microbiota in obesity: Pathogenesis, mechanisms, and therapeutic perspectives. Protein Cell 2018, 9, 397-403. [CrossRef]

169. Chambers, E.S.; Viardot, A.; Psichas, A.; Morrison, D.J.; Murphy, K.G.; Zac-Varghese, S.E.K.; MacDougall, K.; Preston, T.; Tedford, C.; Finlayson, G.S.; et al. Effects of targeted delivery of propionate to the human colon on appetite regulation, body weight maintenance and adiposity in overweight adults. Gut 2015, 64, 1744-1754. [CrossRef]

170. Cani, P.D.; Osto, M.; Geurts, L.; Everard, A. Involvement of gut microbiota in the development of low-grade inflammation and type 2 diabetes associated with obesity. Gut Microbes 2012, 3, 279-288. [CrossRef] [PubMed]

171. Szulińska, M.; Łoniewski, I.; van Hemert, S.; Sobieska, M.; Bogdański, P. Dose-dependent effects of multispecies probiotic supplementation on the lipopolysaccharide (LPS) level and cardiometabolic profile in obese postmenopausal women: A 12-week randomized clinical trial. Nutrients 2018, 10, 773. [CrossRef] [PubMed]

172. Rheinheimer, J.; de Souza, B.M.; Cardoso, N.S.; Bauer, A.C.; Crispim, D. Current role of the NLRP3 inflammasome on obesity and insulin resistance: A systematic review. Metabolism 2017, 74, 1-9. [CrossRef] [PubMed]

173. Wahlström, A.; Sayin, S.I.; Marschall, H.-U.; Bäckhed, F. Intestinal crosstalk between bile acids and microbiota and its impact on host metabolism. Cell Metab. 2016, 24, 41-50. [CrossRef] [PubMed]

174. Ramírez-Pérez, O.; Cruz-Ramón, V.; Chinchilla-López, P.; Méndez-Sánchez, N. The role of the gut microbiota in bile acid metabolism. Ann. Hepatol. 2017, 16, s15-s20. [CrossRef]

175. Schoeler, M.; Caesar, R. Dietary lipids, gut microbiota and lipid metabolism. Rev. Endocr. Metab. Disord. 2019, 20, 461-472. [CrossRef]

176. Zhang, Y.; Lee, F.; Barrera, G.; Lee, H.; Vales, C.; Gonzalez, F.; Willson, T.; Edwards, P. Activation of the nuclear FXR improves hyperglycemia and hyperlipidemia in diabetic mice. Proc. Natl. Acad. Sci. USA 2006, 103, 1006-1011. [CrossRef]

177. Duran-Sandoval, D.; Mautino, G.; Martin, G.; Percevault, F.; Barbier, O.; Fruchart, J.-C.; Kuipers, F.; Staels, B. Glucose regulates the expression of the farnesoid $x$ receptor in liver. Diabetes 2004, 53, 890-898. [CrossRef]

178. Parséus, A.; Sommer, N.; Sommer, F.; Caesar, R.; Molinaro, A.; Ståhlman, M.; Greiner, T.U.; Perkins, R.; Bäckhed, F. Microbiota-induced obesity requires farnesoid X receptor. Gut 2017, 66, 429-437. [CrossRef] 
179. Jiang, C.; Xie, C.; Lv, Y.; Li, J.; Krausz, K.W.; Shi, J.; Brocker, C.N.; Desai, D.; Amin, S.G.; Bisson, W.H.; et al. Intestine-selective farnesoid $\mathrm{X}$ receptor inhibition improves obesity-related metabolic dysfunction. Nat. Commun. 2015, 6, 10166. [CrossRef]

180. Renga, B.; Mencarelli, A.; Vavassori, P.; Brancaleone, V.; Fiorucci, S. The bile acid sensor FXR regulates insulin transcription and secretion. Biochim. Et Biophys. Acta (BBA) Mol. Basis Dis. 2010, 1802, 363-372. [CrossRef] [PubMed]

181. Schugar, R.C.; Shih, D.M.; Warrier, M.; Helsley, R.N.; Burrows, A.; Ferguson, D.; Brown, A.L.; Gromovsky, A.D.; Heine, M.; Chatterjee, A.; et al. The TMAO-producing enzyme flavin-containing monooxygenase 3 (FMO3) regulates obesity and the beiging of white adipose tissue. Cell Rep. 2017, 19, 2451-2461. [CrossRef] [PubMed]

182. Bennett, B.J.; de Aguiar Vallim, T.Q.; Wang, Z.; Shih, D.M.; Meng, Y.; Gregory, J.; Allayee, H.; Lee, R.; Graham, M.; Crooke, R.; et al. Trimethylamine-N-oxide, a metabolite associated with atherosclerosis, exhibits complex genetic and dietary regulation. Cell Metab. 2013, 17, 49-60. [CrossRef] [PubMed]

183. Gao, J.; Xu, K.; Liu, H. Impact of the gut microbiota on intestinal immunity mediated by tryptophan metabolism. Front. Cell. Infect. Microbiol. 2018, 8, 13. [CrossRef]

184. Konopielski, P.; Ufnal, M. Indoles-gut bacteria metabolites of tryptophan with pharmacotherapeutic potential. Curr. Drug Metab. 2018, 19, 883-890. [CrossRef]

185. Bendheim, P.E.; Poeggeler, B.; Neria, E.; Ziv, V.; Pappolla, M.A.; Chain, D.G. Development of indole-3-propionic acid (OXIGON) for Alzheimer's disease. J. Mol. Neurosci. 2002, 19, 213-217. [CrossRef]

186. Dehhaghi, M.; Panahi, H.K.S.P.; Guillemin, G.J. Microorganisms, tryptophan metabolism, and kynurenine pathway: A complex interconnected loop influencing human health status. Int. J. Tryptophan Res. 2019, 12, 1-10. [CrossRef]

187. Dodd, D.; Spitzer, M.; Van Treuren, W.; Merrill, B.D.; Hryckowian, A.J.; Higginbottom, S.K.; Le, A.; Cowan, T.M.; Nolan, G.P.; Fischbach, M.A.; et al. A gut bacterial pathway metabolizes aromatic amino acids into nine circulating metabolites. Nature 2017, 551, 648-652. [CrossRef]

188. Krishnan, S.; Ding, Y.; Saedi, N.; Choi, M.; Sridharan, G.V.; Sherr, D.H.; Yarmush, M.L.; Alaniz, R.C.; Jayaraman, A.; Lee, K. Gut microbiota-derived tryptophan metabolites modulate inflammatory response in hepatocytes and macrophages. Cell Reports 2018, 23, 1099-1111. [CrossRef]

189. Tenorio-Jiménez, C.; Martínez-Ramírez, M.J.; Gil, Á. Gómez-Llorente, C. Efects of probiotics on metabolic syndrome: A systematic review of randomized clinical trials. Nutrients 2020, 12, 124. [CrossRef]

190. Zeevi, D.; Korem, T.; Zmora, N.; Israeli, D.; Rothschild, D.; Weinberger, A.; Ben-Yacov, O.; Lador, D.; Avnit-Sagi, T.; Lotan-Pompan, M.; et al. Personalized nutrition by prediction of glycemic responses. Cell 2015, 163, 1079-1094. [CrossRef] [PubMed]

(C) 2020 by the authors. Licensee MDPI, Basel, Switzerland. This article is an open access article distributed under the terms and conditions of the Creative Commons Attribution (CC BY) license (http://creativecommons.org/licenses/by/4.0/). 